\title{
Denitrification and Dilution along Fracture Flowpaths Influence the Recovery of a Bedrock Aquifer from Nitrate Contamination
}

\author{
*Jonathan J. Kim ${ }^{1}$, Jeff Comstock ${ }^{2}$, Peter Ryan ${ }^{3}$, Craig Heindel ${ }^{4}$, and Stephan Koenigsberger ${ }^{3}$ \\ * Corresponding Author jon.kim@vermont.gov
}

${ }^{1}$ Vermont Geological Survey, 1 National Life Drive, Main 2, Montpelier, Vermont 05620

${ }^{2}$ Vermont Agency of Agriculture, 116 State Street, Montpelier, Vermont 05620

${ }^{3}$ Dept. of Geology, Middlebury College, Middlebury, Vermont 05753

${ }^{4}$ Waite-Heindel Environmental Management, 7 Kilburn Street, Suite 301, Burlington, VT 05401 


\begin{abstract}
In 2000, elevated nitrate concentrations ranging from 12 to $34 \mathrm{mg} / \mathrm{L} \mathrm{NO}_{3}-\mathrm{N}$ were discovered in groundwater from numerous domestic bedrock wells adjacent to a large dairy farm in central Vermont. Long-term plots and contours of nitrate vs. time for bedrock wells showed "little/no", "moderate", and "large" change patterns that were spatially separable. The metasedimentary bedrock aquifer is strongly anisotropic and groundwater flow is controlled by fractures, bedding/foliation, and basins and ridges in the bedrock surface. Integration of the nitrate concentration vs. time data and the physical and chemical aquifer characterization suggest two nitrate sources: a point source emanating from a waste ravine and a non-point source that encompasses the surrounding fields. Once removed, the point source of $\mathrm{NO}_{3}$ (manure deposited in a ravine) was exhausted and $\mathrm{NO}_{3}$ dropped from $34 \mathrm{mg} / \mathrm{L}$ to $<10 \mathrm{mg} / \mathrm{L}$ after $\sim 10$ years; however, persistence of $\mathrm{NO}_{3}$ in the 3 to $8 \mathrm{mg} / \mathrm{L}$ range (background) reflects the long term flux of nitrates from nutrients applied to the farm fields surrounding the ravine over the years predating and including this study. Inferred groundwater flow rates from the waste ravine to either moderate change wells in basin 2 or to the shallow bedrock zone beneath the large change wells are $0.05 \mathrm{~m} /$ day, well within published bedrock aquifer flow rates. Enrichment of ${ }^{15} \mathrm{~N}$ and ${ }^{18} \mathrm{O}$ in nitrate is consistent with lithotrophic denitrification of $\mathrm{NO}_{3}$ in the presence of dissolved $\mathrm{Mn}$ and Fe. Once the ravine point-source was removed, denitrification and, to a lesser extent, dilution were responsible for the down-gradient decrease of nitrate in this bedrock aquifer. Denitrification was most influential when $\mathrm{NO}_{3}-\mathrm{N}$ was $>10 \mathrm{mg} / \mathrm{L}$. Our multidisciplinary methods of aquifer characterization are applicable to groundwater contamination in any complexly-deformed and metamorphosed bedrock aquifer.
\end{abstract}




\section{Keywords}

Point-source, non-point source, monitoring, planar structures, anisotropy, nutrient management 


\section{Introduction}

Fractured igneous, metamorphic and well-cemented sedimentary rocks cover about 50\% of the earth's land surface, including extensive areas on all continents; in these areas, the dominant groundwater reservoir is fractured crystalline rock (Singhal and Gupta, 2010). Fractured rock aquifers (FRAs), also known as bedrock aquifers or crystalline rock aquifers, are important for many reasons — they are less prone to drought, they are the only reliable groundwater resource for people living on one-half of earth's land surface, and many have not yet been tapped - yet research on this aquifer type is sparse relative to the extensive body of research on unconsolidated aquifers (Krásný et al 2014). In particular, studies of contaminant behavior in FRAs are limited, including the fate, transport and remediation of nitrate (e.g. Levison and Novakowski 2009; Landig et al., 2011; Chapman et al., 2015). It is often assumed that long periods of time are required for remediation of nitrate-contaminated groundwater once the nitrogen source is removed; perhaps for this reason (i.e. long recovery time), the literature contains very few examples of natural attenuation and remediation of a FRA in response to implementation of best management practices (BMPs) designed to minimize nitrogen loading (Rudolph, 2015).

In most cases, nitrate contamination of groundwater can be traced to either human waste (septic, sewage) or agriculture; in the latter case, application of manure or fertilizer to boost crop yields, or improper storage of manure, is the likely source of aquifer contamination (Levison \& Novakowski 2009; Best et al., 2015). Once nitrogen is at the surface or in soil, fate and transport of nitrate into a FRA is mainly controlled by biochemical factors (e.g. plant uptake, microbial transformations) and geological factors (e.g. fracture distribution, thickness, permeability of overlying sediment). Infiltration of nitrate (or precursor $\mathrm{N}$ phase) is limited by plant uptake, so $\mathrm{N}$ 
applications exceeding plant uptake capacity are prone to leaching toward the water table (Wick et al., 2012). Seasonal or inter-annual changes in primary productivity may impart cyclic effects on inputs of nitrate into groundwater (Williard et al., 2004). Dissolved organic carbon in FRAs is frequently so low that denitrification may not occur - this is because denitrifying bacteria populations are too small (Levison \& Novakowski., 2009). When overlying sediment is permeable or absent (leaving exposed fractures at the surface), infiltration tends to be rapid. FRAs that possess wide, well-connected fractures tend to be more vulnerable to nitrate contamination than unconsolidated aquifers, and well-developed fractures may limit lateral dispersion of nitrate in FRAs compared to unconsolidated aquifers, thus leading to longerdistance transport along linear features (Kauffman et al., 2001; Kozuskanich et al., 2014).

When fertilizer, septic waste or manure is added to the land or shallow subsurface it undergoes a series of transformations before ultimately forming nitrate. The transformation of urea or $\mathrm{NH}_{4}{ }^{+}$to nitrate typically occurs over days to weeks depending on variables such as temperature, soil texture and $\mathrm{pH}$ (Venterea and Rolston, 2000). If nitrate is transported to suboxic groundwater or anaerobic soils, it may undergo denitrification to $\mathrm{N}_{2}$ or, less commonly, to $\mathrm{N}_{2} \mathrm{O}$, often in the presence of bacteria such as Pseudomonas (Canter, 1997).

In October of 2000, the Vermont Agency of Agriculture (VAA) discovered that groundwater from a number of domestic bedrock wells adjacent to a large dairy farm in central Vermont had nitrate levels that exceeded the 10 parts per million $(\mathrm{mg} / \mathrm{L})\left[\mathrm{mg} \mathrm{l}^{-1}\right.$ as $\left.\mathrm{NO}_{3}-\mathrm{N}\right]$ EPA maximum contaminant level (MCL) (Figure 1). The consumption of groundwater with elevated nitrate levels is associated with methemoglobinemia (blue baby syndrome) and other health issues such as cancer (Ward et al., 2005); it also negatively impacts aquatic ecosystems by contributing to eutrophication (Canter, 1997; Paerl et al., 2015; Zebarth et al., 2015). Because 
nitrate contamination of groundwater in the vicinity of dairy farms is commonly derived from the degradation of nutrients such as cow manure, commercial fertilizer and crop residues (Nolan and Hitt, 2006b), farm nutrient management practices were generally suspected to be the source; there are no natural sources of nitrate in the bedrock or surficial materials such as reported elsewhere by Ericksen (1981). New nutrient management practices were revised almost immediately by the farm for the fields in Figure 1 that are encompassed by the affected domestic bedrock wells to reduce non-point source nitrate infiltration by: 1) suspending the application of manure and fertilizer for several years; and 2) increasing the number of years for grass/hay and decreasing the number of years for corn in the field crop rotations. Five years prior (1995), a bedrock ravine that contained farm waste (including manure) and debris that was a potential nitrate point source in the farm fields (Figure 1) was cleaned out and filled with soil.

The discovery of the nitrate problem in 2000 led the VAA to institute a groundwater monitoring program of bedrock wells at this farm that spanned $\sim 12$ years, during which the Vermont Geological Survey became involved. A collaborative study was initiated to study the fate and transport of nitrate in wells completed in different parts of a fractured bedrock aquifer that was impacted by agriculturally-derived nitrates, from point and non-point sources. The major objectives of this study are: 1) To examine patterns of nitrate concentration vs. time for all wells (and selected springs) in the field area to look for spatial and temporal trends; 2) To comprehensively characterize the bedrock aquifer using physical methods (structural geology, geophysical surveys, electromagnetic induction and borehole camera, well log analysis, potentiometric contours) and chemical methods (major and trace element groundwater chemistry, groundwater recharge ages, and nitrogen and oxygen isotopic ratios for nitrates in groundwater); and 3) To integrate the nitrate concentration vs. time spatial and temporal trends 
with the bedrock aquifer characterization and construct an accurate conceptual model. Through this process, the roles of dilution and denitrification in the nitrate evolution of the aquifer will be assessed, as will the discrimination of point vs. non-point nitrate sources. Finally, given the recent summary of Rudolph (2015) indicating that the fate and transport of nitrate in surficial and bedrock aquifers is poorly understood, we stress the applicability our methodology to the study and prediction of groundwater flow — and the fate of pollutants — in fractured rock aquifers globally, particularly in agricultural regions.

\section{Study Area}

\subsection{Geographic Setting}

The entire dairy farm encompasses approximately 220 hectares in the Town of East Montpelier, Washington County, in the central Appalachians of Vermont, USA (Figures 1 and 2). The farm is home to $\sim 700$ milk-producing cows and $\sim 450$ heifers. Topography is characterized by rolling ESE-WNW trending ridges and valleys of the Vermont Piedmont Physiographic Province (e.g. Johnson, 1998). Domestic wells in the area are shown on Figure 1 as red circles and those wells that have exceeded the $10 \mathrm{mg} / \mathrm{L}$ nitrate $\left(\mathrm{NO}_{3}-\mathrm{N}\right) \mathrm{MCL}$ are denoted with black crosses. Wells 928, 935, 691, and 1040 are associated with the farm and with the drainage area around the main farm/production area. The field area for this study encompasses 90 hectares in the northern half of Figure 1 and involves the domestic bedrock wells on Lyle Young Road surrounding the large field and those on Rock Road to the west. The locations of monitor wells installed in 2005 and used for a year are also shown as are bedrock spring locations. 
The Town of East Montpelier is rural and residents overwhelmingly depend on groundwater for potable water. The average annual precipitation in this area is $0.86 \mathrm{~m}$ and calculations by The Johnson Company (1995) indicate that approximately $0.23 \mathrm{~m}(27 \%)$ of recharge remains after accounting for losses of $0.38 \mathrm{~m}(44 \%)$ and $0.25 \mathrm{~m}(29 \%)$ due to surface runoff and evapotranspiration, respectively.

The elliptical brown polygon $\sim 120 \mathrm{~m}$ long and $9 \mathrm{~m}$ deep in the center of Figure 1 is a bedrock ravine that was filled with farm waste (including manure) and debris over parts of the life of the farm. When cleaned out in 1995 to remove the manure, the ravine was backfilled with rocks, stumps, old silage and hay, and then capped with soil. At present, this former ravine is completely filled to the grade of the surrounding land. The ravine and surrounding fields will be discussed as nitrate point and non-point sources, respectively.

\subsection{Bedrock Geology}

The study area is underlain by Late Silurian-to-Early Devonian-age metasedimentary rocks of the Waits River Formation of the Connecticut Valley Belt, a geologic province that extends $1100 \mathrm{~km}$ from Connecticut (USA) to the Gaspe Peninsula in Quebec (Canada) (Figure 2 and inset). The Waits River Formation consists of rusty-weathering dark gray phyllites interlayered with brown-weathering, quartzose marbles which can be subdivided into thickly (1 $5 \mathrm{~m})$ and thinly- bedded (0.2 - $3 \mathrm{~m})$ members, based on thickness of marble layers (Kim et al., 2010; Walsh et al. 2010; Kim and Ruksznis, 2011; Kim et al., 2015). The general mineralogy of the phyllites is chlorite-plagioclase-quartz-muscovite +/- biotite, garnet and pyrite, whereas that of the quartzose marbles is calcite-quartz-muscovite +/- pyrite (Walsh et al., 2010). The thicklybedded unit underlies the study area. At some outcrops, marble beds are relatively unweathered; 
however, at other outcrops the marble beds are strongly weathered and porous, with significant secondary porosity produced by dissolution of calcite.

\subsection{Structural Geology}

These rocks were deformed and metamorphosed to garnet-grade during the Devonian Acadian Orogeny. Based on field mapping by Kim et al. (2003), Walsh et al. (2010), Kim et al. (2010), Kim and Rukznis et al. (2011a), and Kim et al. (2015), the NNE-striking and steeply west-dipping dominant foliation $\left(S_{1}\right)$ in the Waits River Formation is a spaced cleavage that is sub-parallel to bedding and axial planar to upright to reclined tight- isoclinal folds $\left(\mathrm{F}_{1}\right)$. A second folding event $\left(\mathrm{F}_{2}\right)$ locally deforms $\mathrm{S}_{1}$ into tight asymmetric folds with a shallowly-to-moderately west-dipping axial planar crenulation cleavage $\left(\mathrm{S}_{2}\right)$. In terms of regional structures, the field area is situated on the west limb of the map-scale $F_{1}$ Townshend- Brownington Syncline (Hall, 1956).

Extension fractures in the field area formed during the Cretaceous period (McHone, 1978; Faure et al., 1996). The dominant fracture set in the field area dips moderately-to-steeply and strikes east-west and is nearly orthogonal to bedding $/ \mathrm{S}_{1}$. A subordinate fracture set also dips steeply and strikes NW-SE. All fractures are generally more strongly developed in the phyllites vs. the marbles.

\subsection{Surficial Geology}

The surficial geology of the field area consists of glacial till on ridges and isolated peat and muck deposits in intervening valleys. Glaciolacustrine silty clays and glaciofluvial sands and gravels occur in the Winooski River valley well to the east (Stewart and MacClintock, 1970). The site-specific surficial geology of the farm area was determined from logs of monitoring 
wells and excavator pits, which show that the till is gray to light brown silty sand with pebbles and cobbles of locally-derived Waits River Formation within $3 \mathrm{~m}$ of the surface. The average matrix composition is $49 \%$ sand, $42 \%$ silt, and $9 \%$ clay (Springston, 2010, pers. comm.). Below this depth, at some locations, the till consists of silty sand.

\subsection{Soils}

Soil series in the vicinity of the farm are the Buckland and Cabot silt loams, the Dummerston fine sandy loam, and the Vershire-Dummerston and Glover-Vershire complexes. These soil types were derived from the weathering of glacial till (Gourley et al. 2004). The Dummerston fine sandy loam and the Vershire-Dummerston Complex soils comprise most of the field area are both porous and permeable and rated as "well drained".

\subsection{Wells}

Domestic wells in the field area (Figure 1) are exclusively bedrock wells that range from 12 - 50 $\mathrm{m}$ in depth. Overburden thicknesses for these wells vary from $1-30 \mathrm{~m}$. The composition of the overburden was previously discussed in the surficial geology and soils sections. All wells are $0.15 \mathrm{~m}$ in diameter, with open boreholes in bedrock below the casing. Casings were generally sealed into a short "socket", typically drilled 1-2 m into the bedrock surface, by means of a pounded drive shoe on the bottom of the casing. Three monitor wells were completed in bedrock (13 - $17 \mathrm{~m}$ depths) for this study (Figure 1) and each well was $0.15 \mathrm{~m}$ in diameter and had two nested piezometers, one at the overburden - bedrock interface and the other in the bedrock aquifer. General statistics for each well can be found in Table DR-1. 


\section{Sampling, Analytical, and Surveying Techniques}

\subsection{Sampling of Groundwater}

Over a 12-year period, groundwater samples from domestic wells were obtained from outdoor or indoor faucets after letting the water run for $\sim 10$ minutes, so as to procure water directly from the well. Because it was not possible to sample all wells in the field area in one day, groundwater samples for nitrate analysis were taken over periods that ranged from several days to two weeks; the date assigned to the sampling interval was the date on which most samples were taken. Bladder pumps were used to sample the three monitoring wells that were installed in 2005 for six months. A calibrated Yellow Springs International (YSI) multi-meter was used to monitor temperature, electrical conductivity, $\mathrm{pH}$, dissolved oxygen, and oxidation-reduction potential prior to sampling groundwater from domestic and monitoring wells for the same six months.

\subsection{Sampling and Analysis of CFCs and Calculation of Recharge Ages}

Chlorofluorocarbon (CFC) measurements were performed at the Tritium Laboratory at the Rosenstiel School of Marine and Atmospheric Sciences at the University of Miami (Florida), USA following standard procedures designed to avoid contamination. CFC ages are generally expressed as "average recharge age" because of mixing; i.e., water of multiple ages (different sources) may recharge any given aquifer, creating an intermediate age (Cook and Herczeg, 2000). Given that CFCs have been used as refrigerants and in plastics and electronics manufacturing, additional sources of CFCs outside of meteoric water can introduce error.

CFC ages were obtained for wells MW2D, 1039, 1063, 1065, 1068, and 1070, sampled twice each for CFC analysis (July and November 2005). Each sample consisted of three separate 
glass bottles, which were analyzed separately by Tritium Laboratory. For both sampling events, only CFC-113 ages could be reliably determined for all wells.

\subsection{Groundwater Hydrochemical and Nitrate Isotopic Analyses}

Concentrations of metals and anions in groundwater were analyzed at the Vermont Department of Environmental Conservation Laboratory in Waterbury, Vermont, USA. Samples for trace metal analysis were acidified with ultra-pure $\mathrm{HNO}_{3}$ to $\mathrm{pH}<2$ before analysis, and analytical methods are as follows: ICPMS was used to determine concentrations of metals and metalloids (Al, Sb, As, Ba, Be, Cd, Ca, Cr, Co, Cu, Fe, Pb, Mg, Mn, Mo, Ni, K, Se, Ag, Na, Sr, Tl, , U, V, and Zn) according to EPA method 6020; $\mathrm{Cl}^{-}$was determined by either EPA 300.0 or SM 4500CL-G; P was determined by SM 4500-PH; $\mathrm{SiO}_{2}$ by $\mathrm{SM} 4500 \mathrm{SiO}_{2}-\mathrm{F}$, and alkalinity by SM 2320B. Analyses of $\mathrm{NO}_{3}$ in groundwater were performed by ion chromatography (EPA method 300.0) at the former VAA Laboratory in Waterbury, Vermont, and all nitrate concentrations are reported in units of $\mathrm{mg} / \mathrm{L} \mathrm{NO}_{3}-\mathrm{N}$. Analysis of nitrogen and oxygen isotope compositions of nitrate in groundwater were performed at the Environmental Isotope Laboratory at the University of Waterloo, Ontario, Canada. Values are reported in delta notation relative to atmosphere with estimated precisions of $0.5 \%$ for $\delta^{15} \mathrm{~N}$ and $0.8 \%$ for $\delta^{18} \mathrm{O}$ in $\mathrm{NO}_{3}{ }^{-}$.

\subsection{Geophysical Surveying}

An electromagnetic induction (EMI) grid survey was carried out across the bedrock ravine and northward (down-gradient) by the National Resource Conservation Service (NRCS) in collaboration with the Vermont Agency of Agriculture. EMI is effective for detecting conductivity contrasts generated by water content, salinity, and clay (e.g. Telford et al., 1976); in 
this case, the EMI surveys provided critical constraints on the subsurface bedrock structure. For the Geonics EM-31 instrument utilized, a vertical dipole survey resulted in depths of penetration $4.1 \mathrm{~m}$ that were approximately double those of horizontal dipole surveys $(2.0 \mathrm{~m})$.

\subsection{Borehole Camera Surveys}

In order to perform a borehole camera survey of a well: 1), the pump, wiring, and pipes were pulled out of the borehole and laid out on the ground; 2) a one-half horsepower pump was lowered down the borehole and the groundwater was pumped out; and 3) the borehole camera followed the pump down the borehole to survey/videotape the evacuated well and identify the groundwater producing interval(s). A plastic sampling tube was installed from the top of the well to this depth for groundwater sampling during May - October 2005.

\section{Results}

\subsection{Nitrate vs. Time Data}

\subsubsection{Long-Term}

As part of its monitoring program of water quality around large farms, the VAA collected and analyzed groundwater samples from bedrock wells for nitrates on a regular basis in the farm area from 2000-2013 (Table DR-2). All nitrate data were plotted on nitrate vs. time plots to see how nitrate concentrations had changed over a decade of sampling. Three general patterns were recognized and plotted separately.

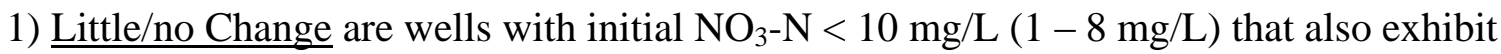
little or no change with time (Type I pattern, Figure 3A); The Type I well trends are 〜horizontal lines. 
2) Moderate Change are wells with initially-elevated nitrate concentrations (11 - 17 $\mathrm{mg} / \mathrm{Lmg} / \mathrm{L}$ ) that slowly decreased to $<10 \mathrm{mg} / \mathrm{L} \mathrm{NO}_{3}-\mathrm{N}$ over the $2000-2013$ period (Type II pattern, Figure 3B). Some large variations in nitrate concentrations between adjacent sampling events suggest influence from shallow infiltrating surface water.

3) Large Change are wells with initially-high nitrate $\left(\sim 21-29 \mathrm{mg} / \mathrm{L} \mathrm{NO}_{3}-\mathrm{N}\right)$ that exhibit rapid decrease to $<7 \mathrm{mg} / \mathrm{L}$, then experience little or no change from 2005 - 2013 (Type III pattern, Figure 3C). Like the moderate change group, these patterns also show large differences in nitrate concentrations between successive sampling events that may reflect the influence of shallow infiltrating surface water.

One bedrock spring (s1343) was monitored for nitrate concentrations for 10 years and is our only control on the nitrate concentrations away from Lyle Young Road. Because the nitrate pattern of s1343 is similar to that of "Moderate change" well 1039 and it is approximately the same north-south distance from the ravine as 1039, these wells are shown together in Figure 3D. Figure 4 shows the spatial distribution of the wells in each nitrate group on a base map.

\subsubsection{Evidence for Surface Water Influence}

Two of the Type II "moderate-change" wells (1039 and 1074) are from a cluster of wells on the north side of Lyle Young Road (Figure 4). During the 30-April-2001 sampling event, nitrate concentration in well 1074 had increased whereas nitrate in well 1039 decreased relative to the previous sampling event (Figure 3B). Just prior to this sampling period, a $0.94 \mathrm{~m}$ snowpack melted in a $~ 2$-week period, providing a large volume of infiltrating surface water to the bedrock aquifer that apparently diluted nitrate in some wells while simultaneously causing 
nitrate to increase in nearby wells. This event only influenced the nitrate concentrations for one quarter (i.e. 3 months) and then concentrations "recovered" to the baseline. Superposed on the steeply declining nitrate patterns shown by Type III wells are pronounced negative nitrate anomalies associated with annual April snowmelts through the first half of the record (Figures 3C). Like the wells in Type II, these anomalies are consistent with infiltration of the bedrock aquifer by shallow infiltrating surface water facilitated by the permeable surficial materials; once in bedrock, groundwater flow is controlled by a network of planar structures (bedding planes, foliations, and fractures).

\subsubsection{Short Term}

In addition to nitrate level data that were acquired at roughly a quarterly basis over a $\sim 12-$ year period, nitrates were also determined on a monthly interval over the 6-month period from May to October 2005 for most of the same wells (Table DR-2) to provide insight into short-term fluctuations. It is important to note that MW1D, MW2D, and MW3D are the only wells that tap the bedrock aquifer directly beneath the farm fields in Figure 1. The following wells have generally similar patterns: MW1D and MW3D and 1063, 1065, and 1039. For this 6-month period, well 1070 exhibits inverse behavior compared to 1039, 1063 and 1065 (when 1070 decreases, the other 3 increase, and vice versa) (Figure 5). Wells 1068 and MW1D and spring 1343 each show very little change; wells MW2D and MW3D both progressively decrease in concentration of $\mathrm{NO}_{3}$ over the 6 months (Figure 5). The similar form of the patterns for MW2D and MW3D (decreasing $\mathrm{NO}_{3}$ over this 5-month period) is important in the overall nitrate history in terms of nitrate sources, which are discussed in a later section. 


\subsubsection{Contouring of Nitrate vs. Time}

The nitrate data for all wells and one spring were contoured for a 10-year period (out of 12-year total) as a time-series so that spatial patterns could be observed. The time slices were selected approximately two years apart or at times of significant change. Since monitor wells MW1D, MW2D, and MW3D were installed in May 2005 and abandoned in 2006, nitrate data for these wells was only briefly available. The minimum contour line for these maps is $5 \mathrm{mg} / \mathrm{L}$ and the contour interval is $5 \mathrm{mg} / \mathrm{L}\left(\mathrm{NO}_{3}-\mathrm{N}\right)$. Some wells had isolated sampling gaps. The highlights of the time slices are described below and shown in Figure 6:

Time I- 10-31-2000 When the nitrate contamination problem was first discovered by the VAA in the fall of 2000 (Time 1), "Large-change" wells in the shallow bedrock zone had nitrate concentrations that were $\sim$ double those to the west; the highest values (25 to 30 $\mathrm{mg} / \mathrm{L}$ ) occurred in wells 1073 and 1065 . West of these wells, the highest nitrate value was $15 \mathrm{mg} / \mathrm{L}$ in well 1039 . Well 1063 , which is far to the southeast, had a nitrate value of $10.3 \mathrm{mg} / \mathrm{L}$.

Time II- 10-22-2002 The same basic nitrate contour pattern persisted as at Time 1, but at lower concentrations. Nitrate values $\sim 10 \mathrm{mg} / \mathrm{L}$ persisted in the distal well 1063 . Time III- 12-09-2004 After two more years, nitrate concentrations had diminished by -50-99\% in the "large-change" group and by 10-28\% in the "moderate-change" well group in the northern portion of the field area. Well 1070 decreased from 11.9 to 0.1 $\mathrm{mg} / \mathrm{L}$. Nitrate values $\sim 10 \mathrm{mg} / \mathrm{L}$ again persisted in well 1063 . This is the last time slice where nitrate concentrations are higher in Type II "large-change" wells compared to the other two types. It appears that the source of nitrates to wells in this part of the field area was nearly exhausted at this time. 
Time IV-11-04-2005 This slice from 11 months later is shown because all nitrate concentrations from wells in the "large-change" group were $<10 \mathrm{mg} / \mathrm{L}$ and lower than those in the northern "moderate-change" group, further supporting the complete exhaustion of a nitrate source.

Time V (4-03-2007) and Time VI (2-10-2009) From 17 and 39 months after Time IV, there are no appreciable differences in nitrate concentrations between the northern "moderate-change" well group and the "large-change" well group, likely indicating that the bedrock aquifer has returned to "background" nitrate concentrations after exhaustion of an ephemeral (point) nitrate source. In this case, background is defined as $7.3 \mathrm{mg} / \mathrm{L}$ based on the mean of well 1068 (highest long-term value of "little/no change" wells); this value is consistent with the long-term mean of "large-change" and "moderate-change" wells once they have reached (an apparent) long-term steady state, post-2006 (Figure 3). "Background" nitrate concentrations represent those perpetuated in the bedrock aquifer by the non-point source application of nutrients to upgradient farm fields (Figure 1) over the years predating and including this study; they are not "natural" background concentrations.

To summarize the long-term nitrate vs. time patterns and contouring, we now calculate the time that the well groups took to decline from their highest nitrate level after monitoring started $\left(\mathrm{N}_{\mathrm{h}}\right)$ to below the nitrate background level of $7.3\left(\mathrm{~N}_{\mathrm{b}}\right)$; this is the duration to exhaust the point source for each well group. The "large-change" wells started at $\mathrm{N}_{\mathrm{h}}$ concentrations of $27.5-$ $33.7 \mathrm{mg} / \mathrm{L}$ and took $4.0-4.7$ years to decrease from $\mathrm{N}_{\mathrm{h}}$ to $\mathrm{N}_{\mathrm{b}}$ at rates of $5.4-8.8 \mathrm{mg} / \mathrm{L} /$ year. $\mathrm{N}_{\mathrm{h}}$ concentrations of $11.5-27 \mathrm{mg} / \mathrm{L}$ for "Moderate-change" wells required $3.6-7.8$ years to 
decrease to $\mathrm{N}_{\mathrm{b}}$ concentrations at rates of $0.8-4.9 \mathrm{mg} / \mathrm{L} /$ year. Nitrate concentrations in "Little/No-change" wells are presumed to represent background.

\subsection{Aquifer Characterization}

The nitrate data described in the previous section clearly show that zones within the bedrock aquifer responded differently spatially and temporally over a $\sim 10$-year period (out of a 13-year total) to the evolution of two different nitrate sources, i.e. a point source and a non-point source. In order to understand the context for this evolution, comprehensive aquifer characterization was carried out, which included physical and chemical methods.

\subsubsection{Physical Methods}

\subsubsection{Bedrock Structural Analysis}

Detailed bedrock geologic mapping in the field area was conducted by Kim et al. (2003) and lithologies and structures were examined at 85 bedrock outcrops. Planar structures in Waits River Formation bedrock aquifer are comprised of a NNE-SSW striking moderately-to-steeply west-dipping foliation $\left(\mathrm{S}_{1}\right)$ that is locally overprinted by a moderately west-dipping axial planar

crenulation cleavage $\left(\mathrm{S}_{2}\right)$. The dominant fracture set in the field area dips moderately-steeply and strikes east-west, $\sim$ orthogonal to bedding $/ S_{1}$. Rose diagrams and equal area nets graphically show the attitude of the $S_{1}$ foliation (Figure 7A, 7B), as well as that of the dominant and subordinate (NW-SE striking) fracture sets. Equal area nets separately plot poles to foliation and fracture planes. (Figure 7C, 7D). A thematic block diagram that shows the three planar structure sets is shown in Figure 7E.

\subsubsection{The Bedrock Surface Contour Map}


Using bedrock geologic maps and logs of domestic and monitor wells, a bedrock surface contour map was constructed (Figure 8). Depth to bedrock and well elevation data on which this map is based are shown in Table DR-1. In addition, the overburden thickness is shown above each well or spring location in lieu of a separate isopach map. The numerous bedrock outcrops at the top of the ridge in the central part of the field area (Figure 7) indicate that the till overburden is locally thin or absent (e.g. $<1 \mathrm{~m}$ ). Farther to the west, north, and east, till deposits fill small bedrock basins (Figure 7). The western basin (basin 1) is an elliptical depression parallel to the dominant NNE-foliation in the bedrock (Figure 7A. 7B) and is filled with up to $27 \mathrm{~m}$ of overburden. The basin in the northwestern part of the field area (basin 2) is bounded to the east by a small NNE- trending bedrock ridge between wells 1039 and 1074. Basin 2 has a maximum overburden thickness of $15 \mathrm{~m}$. East of basin 2 and the small intervening bedrock ridge is a shallow depth to bedrock zone (0.6 -1.8 m) surrounding wells 1073, 1065, and 1070. The basin in the southeast part of the field area (basin 3) is likely a buried valley and has overburden thicknesses of up to $24 \mathrm{~m}$ (Figure 7). In a later section, it will be shown that bedrock basin 2 and the shallow bedrock zone exert strong local control on the groundwater flow.

Spatial correlations between the nitrate groups and the bedrock surface contour map are: 1) "large-change" wells are associated with the shallow bedrock zone, 2) "moderate-change" wells straddle the bedrock ridge between basin 2 and the shallow bedrock zone or are isolated in basin 3, and 3)"little/no-change" wells are located in or parallel to basin 1 or between the shallow bedrock zone and basin 3 .

\subsubsection{Electromagnetic Induction (EMI) Surveys}


The EMI survey from the northern end of the waste ravine northward across the farm field toward Lyle Young Road (Figure 9A) was performed because of the possibility that this ravine was a nitrate point source to the bedrock aquifer. Contoured EMI data (Figure 9B and the rose diagram on Figure 9A) shows three linear higher-conductivity segments that intersect north of the ravine and trend northeast ( 24 degrees), east-west ( 87 degrees), and northwest ( 311 degrees). Based on comparisons with bedrock structural data in Figure 7, the NE trend is parallel to the strike of the dominant $S_{1}$ foliation whereas the east-west and northwest trends are parallel to the strike of the dominant and subordinate fracture sets (Figure 7). The source of the higher conductivity is likely the presence of groundwater containing dissolved cations, such as $\mathrm{Ca}$ and $\mathrm{Mg}$ derived from carbonate layers in the Waits River Formation bedrock, in open planar structures such as bedding/foliation and fractures. The bedrock surface contour map (Figure 8) confirms that the depth to bedrock in the EMI survey area is shallow $(0-3 \mathrm{~m})$ and supports the fact that the EMI surveys imaged bedrock structures.

\subsubsection{Potentiometric Contour Map of the Bedrock Aquifer}

In order to construct potentiometric surface contour maps of the bedrock aquifer, the surface elevations of seven domestic bedrock wells, three monitor wells (screened in bedrock and overburden), and four bedrock springs were surveyed and correlated with a known reference elevation (Table DR-1). Undisturbed equilibrium static water levels (recorded at 5:00 AM) were taken two times (9/21/2005 and 11/3/2005) during the study and the potentiometric surface was contoured at $3 \mathrm{~m}$ intervals. The second survey date was used in Figure 10 because the static 
water levels for more wells were measured (November 2005); it is important to note that the potentiometric surface and gradients for both survey dates were very similar.

Figure 10 shows that, at this scale, the potentiometric contours generally agree with the topographic contours, which reflect topography-driven flow in an east-northeast direction from a NW-SE trending ridge on the west side of the study area. In the north-central part of this figure, however, the potentiometric contours make a right-angle bend to the south before continuing eastward. The overall west-to-east flow gradient in the bedrock aquifer in this area is consistent with the attitude of (1) the dominant fracture set, which strikes east - west (70-100 degrees azimuth) (Figure 8) and dips steeply, and (2) the east-west EMI anomaly in Figure 9. Flow gradients in the northern part of the study area are parallel to the strike of the bedrock foliation (20-50 degrees) (Figure 8). The subordinate northwest striking (300-330 degrees) and steeply dipping fracture set shown on Figure 7 does not appear to affect the potentiometric contours at this scale.

It is important to recognize that the potentiometric contour map is only a general model of groundwater flow in the bedrock aquifer in the field area and is limited by the well distribution. Because the coplanar dominant foliation $S_{1}$ and bedding, which contains marble layers with secondary porosity, dip moderately-steeply to the west, we cannot discount the possibility that this surface locally generates westward-directed flow. In addition, the contoured EMI data in Figure 9B suggests a component of groundwater flow from the ravine along northwest striking fractures, after following bedding $/ \mathrm{S}_{1}$; this is parallel to the subordinate fracture set on Figure 8. 


\subsubsection{Surficial Aquifer Evaluation}

Three monitor wells (MW1, MW2, and MW3) were installed in the field area (e.g. Figure 9) in 2005 and each contained two nested piezometers (located at the overburden-bedrock interface, and in saturated zone of the bedrock aquifer; Figure DR3). All glacial overburden was found to be in the vadose zone. Even after heavy rainfall $\sim 0.25 \mathrm{~m}$ within 72 hours), the overburden was unsaturated. For piezometers installed at the overburden-bedrock interface, monthly monitoring over a six-month period only occasionally encountered water - they typically were dry. These observations indicate that the highly-permeable nature of the overburden does not permit the formation of a water table aquifer and that recharge through the overburden is rapid and enters the bedrock aquifer below overburden through fractures and solution-enlarged bedding/foliation planes.

\subsubsection{Borehole Camera Surveys}

Five domestic bedrock wells sampled for nitrates in this study were examined with a borehole camera to identify groundwater-producing horizons. Logs for these wells are shown in DR4. Statistics for wells in the field area are shown in Table DR1. Four of these five wells had elevated (> $10 \mathrm{mg} / \mathrm{L} \mathrm{NO}_{3}-\mathrm{N}$ ) nitrate concentrations (1039, 1065, 1070, and 1063).

The borehole camera surveys of wells 1070 and 1068 demonstrated that groundwater flow dominantly occurs through tilted planar zones, which are likely bedding (weathered marble beds) and/or the $S_{1}$ foliation (Figure 11). The groundwater-producing interval for well 1039 was coincident with the bottom of the borehole, which was just below the bottom of casing, and thus the producing zone could not be imaged. Because the majority of fractures in the study area have dips $>60$ degrees, the chances of intersecting a steeply-dipping fracture with a vertical 
borehole are low. We do not believe, however, that groundwater flows exclusively along bedding/foliation, but merely that that it enters the surveyed wells along these surfaces, after following a composite path comprised by bedding/foliation and fractures.

Well 1063, which is a flowing artesian well in the east-central part of the study area, could not be pumped down, so the camera was lowered down through the water column instead. At a depth of $41 \mathrm{~m}$, the $0.15 \mathrm{~m}$ diameter borehole abruptly widened into a cave of unknown dimensions (Figure 11). Water turbulence increased at the cave depth and flow direction indicated by particulates in the groundwater was opposite above compared to below the cave above the cave, mica flakes flow upward, whereas below they flow downward, thus identifying the cave as a producing interval in this well.

\subsubsection{Chemical Methods}

\subsubsection{Major and Trace Element Geochemistry}

Groundwater analyzed from bedrock wells in the study area have average carbonate hardness $(\mathrm{CH})$ values that range from $90-350 \mathrm{mg} / \mathrm{L}$, which is considered moderately hard to very hard and is consistent with dissolution of the abundant marble layers in the Waits River Formation bedrock. Average Ca concentrations (32-110 mg/L) naturally follow $\mathrm{CH}$ values. All sampled well averages plot near the Ca end-member on a Piper diagram (not shown), and $\mathrm{Sr}$ is positively correlated with $\mathrm{CH}$, data which are consistent with weathering of marble layers. The positive correlation of $\mathrm{Mg}$ with $\mathrm{K}$ may be caused by weathering of biotite in the phyllites. Groundwater geochemical data is shown in Table DR-5.

Anomalously high Mn and Fe were observed in two wells (1070 and MW2D). Average Mn concentrations of $1186 \mathrm{ppb}$ (w1070) and $5653 \mathrm{ppb}$ (MW2D) are substantially higher than 
those of other wells. When the pump in well 1070 was pulled prior to camera logging, it was caked with a sooty black metallic Mn hydroxide crust. In addition to high Mn, well MW2D also had extremely high average dissolved Fe $(53,240 \mathrm{ppb})$ relative to the other wells. The potential relationship between oxidation of dissolved $\mathrm{Mn}$ and Fe and paired nitrate reduction (denitrification) is discussed below. In additional to elevated Mn, water from well 1070, with an average $\mathrm{pH}$ of 6.4 , was the only well with a $\mathrm{pH}<7.0$.

\subsubsection{CFC Recharge Ages}

The CFC-113 age averages for all wells ranged from 17-22 years (Table 1), consistent with "modern" groundwater (e.g. Kim et al., 2014). The precision of the collective ages is compromised by lack of reliable CFC-11 and 12 ages for most wells (Table 1). Whenever the CFC concentration in a groundwater sample is greater than that ever recorded in the atmosphere, a non-atmospheric source of CFC must be present. Although this means that CFC-11 and 12 ages from this study had to be discarded, this contamination prompted evaluation of potential sources of contamination, which in turn shed light on groundwater flow. Old refrigerators had been

buried in the bedrock waste ravine during the second half of the $20^{\text {th }}$ century (A. Cleeve, pers. comm. 2005), making the ravine a likely point source of CFC-11 and 12 that may have been distributed throughout the field area. The conceptual model in the following section takes this into account.

\subsubsection{Nitrogen and Oxygen Isotopes}

The results of $\mathrm{N}$ and $\mathrm{O}$ isotopic analyses of eight wells (sampled in May and August of 2005) show that all samples plot within the animal waste and/or soil organic matter field (Figure 12, 
Table DR-6), helping to narrow $\mathrm{NO}_{3}$ source to these possible origins. In addition to assessing nitrate source, $\mathrm{N}$ and $\mathrm{O}$ isotopic data are also useful in assessing whether or not denitrification (i.e. microbially-driven reduction of $\mathrm{NO}_{3}{ }^{-}$to $\mathrm{N}_{2}$ or $\mathrm{N}_{2} \mathrm{O}$ ) is responsible for attenuation of nitrate - this is because when denitrification occurs, the residual $\mathrm{NO}_{3}{ }^{-}$becomes enriched in the heavier isotopes ${ }^{15} \mathrm{~N}$ and ${ }^{18} \mathrm{O}$ (Mariotti et al., 1988; Kendall, 1998; Pauwels et al., 2000). The denitrification trendlines shown in Figure 12 (Kendall, 1998) closely parallel the downgradient evolution of groundwater, a relationship that is consistent with denitrification. The evidence for and importance of denitrification is discussed further in Section 5.2.

\section{Discussion}

Long-term plots and contours of nitrate concentration vs. time for bedrock wells showed three distinct patterns ("little/no", "moderate", and "large" change) that were spatially separable, and whose distribution was not readily predictable without detailed aquifer characterization. The integration of comprehensive physical (bedrock structural analysis, bedrock surface contour map, EMI survey, potentiometric contour map, surficial aquifer evaluation, and borehole camera surveys) and chemical (major and trace element geochemistry, CFC recharge ages, and nitrogen and oxygen isotopes) aquifer characterization methods with thesnitrate data allowed us to explain the origin and distribution of the three nitrate pattern types in a detailed conceptual model that involves point and non-point sources. This synthesis and model enabled analysis of the roles of denitrification and dilution in the chemical evolution of the fractured bedrock aquifer.

Furthermore, results of this study are compared with other FRA nitrate contamination studies and, finally, the applicability this aquifer characterization methodology elsewhere is presented. 


\subsection{Synthesis and Conceptual Model}

Prior to 1995 , the bedrock ravine was filled with manure and farm waste, including old

refrigerators (R. Hall and A. Cleeve, pers. comm., 2005). Understanding of flow from the ravine is based on structural geologic data (identification of foliations, bedding and fracture planes) and the additional constraints on pathways and gradients provided by EMI data and potentiometric surface data. Results indicate that groundwater containing nitrate and CFC-11 and CFC-12 emanating from the ravine flowed first to the NNE along the bedrock bedding $/ \mathrm{S}_{1}$ foliation and then was bifurcated to the east and NW along fracture zones (Figure 13). East-flowing groundwater following the fracture zone defined by EMI, structural analysis, and potentiometric contours migrated towards the shallow bedrock zone where Type III "large-change" wells 1065, 1070 and 1073 are located, consistent with the presence of groundwater supersaturated in CFC11 and CFC-12 in wells 1065 and (to a lesser extent) 1070. This "NNE then E" path appears to be the main avenue for distributing nitrates from the ravine (Figure 13) and explains why the highest nitrate levels were associated with a shallow bedrock zone and why these levels dissipated relatively quickly; they record exhaustion of the ravine point source to "background" concentrations $\left(\sim 7 \mathrm{mg} / \mathrm{L} \mathrm{NO}_{3}-\mathrm{N}\right)$ over $4.0-4.7$ years at rates of $5.4-8.8 \mathrm{mg} / \mathrm{L} \mathrm{NO}_{3} \mathrm{~N} /$ year. It is uncertain how far ravine-sourced groundwater would have flowed along the NW fracture trend defined by EMI and structural analysis, because the regional potentiometric flow direction in this area is generally east-directed. In addition, even though the potentiometric contours do not show this, the moderate to steep westward dip of the composite $\mathrm{S}_{1} /$ bedding surface cannot be discounted as a mechanism for moving groundwater steeply down-dip to the west, particularly when the marbles have significant secondary porosity.

The Type II "moderate-change" wells 1074, 1039, and 1066 all show the influence of nitrates from the ravine, but not to the same extent as the "large-change" wells. In order to 
distribute groundwater to these wells, the subsurface topography likely plays a role. The bedrock surface contour map in Figure 8 shows a small bedrock ridge between wells 1074 and 1039. If groundwater from the ravine follows bedding and/or foliation to the NNE near the bedrock/overburden surface, the buried ridge could deflect it either westward toward well 1039 or eastward toward well 1074, depending on which side of the ridge the groundwater flowed on. Based on borehole camera surveys, the producing zone for well 1039 is only $3 \mathrm{~m}$ below the overburden/bedrock interface, further supporting this idea. In addition, wells 1039 and 1074 are located in small depressions on either side of this ridge with $9 \mathrm{~m}$ and $6 \mathrm{~m}$ of overburden, respectively. From well 1039, basin 2 deepens westward to $15 \mathrm{~m}$, which would create a potential northwestward gradient for groundwater that flows along the bedrock/overburden interface toward well 1066. Overall, these wells required $\sim 3.6-7.8$ years to show exhaustion of the ravine point source at rates of $0.8-4.9 \mathrm{mg} / \mathrm{L} /$ year.

Well 1063 is included in the "moderate-change" group because of its slowly diminishing nitrate pattern, even though it is not in a contiguous group with wells 1066,1039 , and 1074 . This well is located in the stream valley on the east side of the field area and, based on potentiometric surface data, should ultimately receive groundwater recharge from the ravine (and farm fields) to the west. Thus, we believe that this well also records the long distance exhaustion of the nitrate point source in the ravine, on a time frame similar to wells 1066, 1039, and 1074.

Because we know the ravine was eliminated as a nitrate point source in 1995 and that the plume from the ravine was exhausted at the "large-change" wells in November 2005, hypothetical groundwater flow paths can be used to estimate flow times and rates from the ravine to a "large-change" (1073) and a "moderate-change" (1039) well; these flow paths are only in the X-Y plane. Assuming the manure point source was removed from the ravine in June 1995, and using the EMI anomalies for which the NNE one is scaled, groundwater leaving the ravine to 
the north first followed bedding/foliation for $85 \mathrm{~m}$ and then entered the east-striking fracture zone, which constrained it for $127 \mathrm{~m}$ to well 1073 . The total distance divided by 11.5 years yields a rate of $18.4 \mathrm{~m} /$ year or $0.05 \mathrm{~m} /$ day. Worthington (2015) showed that groundwater often flows along a combination of orthogonal planar structures in fractured carbonate aquifers, with flow along one fracture set dominant over the other, so the composite flow distance along both fracture sets will be considerably greater than the straight-line distance, or in this case, segmented distance, between a point-source and a well(s). A second idealized scenario involves groundwater moving out of the ravine along bedding/ foliation, like previously for $85 \mathrm{~m}$, but then flowing NNW off the west side of the buried bedrock ridge toward well 1039 (144 m) and basin 2. In this scenario, the total distance is $229 \mathrm{~m}$ and the flow rate for 11.5 years is also $0.05 \mathrm{~m} /$ day. A hydraulic conductivity of $0.05 \mathrm{~m} / \mathrm{d}$ is within the range of values expected of fractured carbonate rocks $\left(10^{-3}\right.$ to $10^{2} \mathrm{~m} / \mathrm{d}$; Muldoon et al., 2001).

While WNW- and ENE-directed flow dominated dispersion of ravine-derived $\mathrm{NO}_{3}$, groundwater from this point source also flowed SSW along steeply-dipping bedding and foliation planes and emerged at bedrock spring 1343 (Figure 3D, 13). Given its location south of the ravine point source, the nitrate pattern for bedrock spring 1343 may record the exhaustion of the nitrate plume emanating from the ravine and flowing southward. Although the 1343 nitrate record is incomplete relative to the other wells, it is possible that the last part of the decline, which began at 9/18/2003, represented the last gasp of the nitrate plume migrating south (Figure 3D). Nitrate patterns for spring 1343 (SSW of ravine) and well 1039 ( $\mathrm{N}$ of ravine) are virtually identical. Given that both wells are located along or very close to the NNE/SSW bedding/foliation that coincides with the ravine, and that the ravine sits atop a groundwater 
divide, their parallel behavior likely reflects the depletion of the ravine manure nitrate source from $\mathrm{N}$-directed and $\mathrm{S}$-directed flow off of the main ridge.

In addition to the ravine point source, a non-point source of nitrate to the bedrock aquifer must also be considered in the form of previous and ongoing nutrient spreading on the farm fields that surround the ravine. The overall boundary of these fields is shown in Figure 13. Once the nitrate plume from the ravine point source was exhausted in November 2005, "background" nitrate concentrations for the moderate-change and large-change wells vary between 3 and 8 $\mathrm{mg} / \mathrm{L} \mathrm{NO}_{3}-\mathrm{N}$ (with one $12 \mathrm{mg} / \mathrm{L}$ outlier) over the 2005 to 2009 period (Figures $3 \mathrm{~A}$ and 3B) and from 2005 to 2011 overall, which we believe reflects the varying nitrate concentrations in the bedrock aquifer below the non-point source fields - this is generally similar to nitrate concentrations in Type I "little/no change" wells, i.e. those not affected by the ravine point source because they are farthest up gradient in the WNW of the study area (near Rock Road). Whereas Rock Road wells have relatively low nitrate concentrations ( 3 to $8 \mathrm{mg} / \mathrm{L}$ ), they are high enough to reflect the nitrate influence of the nearby field nutrient management practices. Over the course of this study, it is not readily apparent that the changes in non-point source nutrient management practices (suspending manure and fertilizer application and increasing the grass/ hay proportion of crop rotations) implemented in the fall of 2000 have had any effect on the "background" nitrate concentrations in the bedrock aquifer.

It is important to note that the CFC 113 groundwater ages (17-22 year-old) obtained from bedrock wells in the field area represent an average recharge age, which means that different portions of the sampled groundwater likely have different ages. It is not possible to know how many different recharge ages are averaged together in a sample or series of samples. Since the calculated times for exhaustion of the nitrate point source in the waste ravine are in the $\sim 10$-year 
time frame, we know that the 17-22 year ages are not from a single age source, but rather a blend of groundwater from younger and older sources. Groundwater in this general age range is typically called "modern" (e.g. Kim et al., 2014).

\subsection{Evidence for and Importance of Denitrification}

Enrichment of the heavier isotopes of nitrogen and oxygen $\left(\delta^{15} \mathrm{~N}\right.$ from +5.3 to $+12.4 \%$, $\delta^{18} \mathrm{O}$ from -0.4 to $+4.8 \%$ ) indicate that denitrification contributed to the rapid decreases in nitrate (Figure 12). Dilution alone cannot account for the isotopic enrichment that occurs downgradient (Hiscock et al, 2011). The wells with the strongest evidence for denitrification are the large-change wells, especially well 1070 compared to upgradient wells 1039 and 1065 . When considering nitrate concentrations and isotopic data relative to groundwater flow, if $\mathrm{NO}_{3}$-rich groundwater first flowed NNE from the ravine point source along bedding/foliation (as suggested by EMI and field mapping), then migrated E along the E-W fracture zone, the mostaffected wells would have been the large-change wells 1065, 1073 and 1070 (Figure 1) — these are the wells with the most-rapid declines in nitrate ( 5 to $9 \mathrm{mg} \mathrm{NO}_{3}-\mathrm{N} \mathrm{L}^{-1} \mathrm{yr}^{-1}$ ) following removal of the point source. The downgradient trends of decreasing $\mathrm{NO}_{3}$ in conjunction with

increasing $\delta^{15} \mathrm{~N}$ and $\delta^{18} \mathrm{O}$ are consistent with denitrification, as is the range in isotope enrichment factor $(\varepsilon)$ of -2.5 to -4.0 (Mariotti et al, 1988; Kendall, 1998). Mixing with low- $\mathrm{NO}_{3}$ water appears to also play a role, however, in declining $\mathrm{NO}_{3}$ concentrations.

Denitrification is a reduction reaction, so it must be accompanied by paired oxidation. In fractured rock aquifers where low abundance of organic matter may limit activity of denitrifying bacteria (Levison \& Novakowski 2009), lithotrophic (or autotrophic) denitrification can be 
facilitated by oxidation of dissolved $\mathrm{Mn}^{+2}$ (and/or $\mathrm{Fe}^{+2}$ ) (Metcalf and Robbins, 2013). For example:

$$
5 \mathrm{Mn}^{2+}+2 \mathrm{NO}_{3}^{-}+4 \mathrm{H}_{2} \mathrm{O}=5 \mathrm{MnO}_{2}+\mathrm{N}_{2}+8 \mathrm{H}^{+}
$$

Two wells in particular (MW2 and 1070) had very high dissolved Mn concentrations (700 to 13,000 mg/L), and 1070 contained abundant Mn hydroxide coatings inside the well (including on the well pump). The average $\mathrm{pH}$ of well 1070 is also notably low (6.4), consistent with formation of $\mathrm{H}^{+}$as a product of $\mathrm{Mn}$ oxidation. Given the presence of pyrite in bedrock observed in outcrop, and locally high concentrations of Fe and $\mathrm{Mn}$ in groundwater, it is possible that pyrite and dissolved $\mathrm{Fe}^{+2}$ and $\mathrm{Mn}^{+2}$ played a role as electron donors for lithotrophic denitrification (Frind, 1990; Pauwels et al., 2000; Korom et al., 2012; Tedd et al., 2014).

Denitrification likely was most important during the period of rapid $\mathrm{NO}_{3}$ decrease exhibited in the large-change wells, where declining nitrate at a rate of 5 to $9 \mathrm{mg} / \mathrm{L} \mathrm{NO}_{3}-\mathrm{N}$ per year would have exceeded the capacity of dilution by meteoric water infiltration. This rate is comparable to the median denitrification rate in groundwater systems (Green et al., 2008), is very similar to the lithotrophic denitrification rate measured in laboratory studies (Jorgenson et al 2009), and is also broadly consistent with a $\mathrm{NO}_{3}$ half-life due to denitrification of 1-2 years in lithotrophic systems (Frind, 1990). Dilution alone would likely not have produced concentrations $<5 \mathrm{mg} / \mathrm{L}$, and certainly not if the mixing were occurring with regional background groundwater containing $\sim 7 \mathrm{mg} / \mathrm{L} \mathrm{NO}_{3}-\mathrm{N}$; even if mixing were to take place with nearly-pure meteoric water, $50 \%$ of the water in the aquifer would need to replaced annually with nitrate-free water to produce the observed rates, a scenario possible only if low nitrate groundwater ( $\sim 1 \mathrm{mg} / \mathrm{L})$ flowing southeastward from the Rock Road side of the field area (NW) was involved. Further data arguing against significant dilution by meteoric water are the 
relatively uniform major element concentrations in groundwater (DR5), which should depict decreasing concentrations if direct infiltration of dilute meteoric water were strongly influencing groundwater chemistry (Boy-Roura et al., 2013). Isotopic evidence also argues against significant dilution by meteoric water, which tends to contain dilute concentrations of $\mathrm{NO}_{3}$ with $\delta^{15} \mathrm{~N}$ close to $0 \%$, thus unlikely to produce the increasing $\delta^{15} \mathrm{~N}$ trend observed (Kendall, 1998). Tedd et al. (2014) also found that infiltration and dilution by meteoric water did not significantly affect nitrate concentration in a fractured rock aquifer system.

Nitrate threshold concentrations for denitrification are usually relatively low, e.g. 2 to 5 $\mathrm{mg} / \mathrm{L} \mathrm{NO}_{3}-\mathrm{N}$ (Ryden, 1983; Barton et al., 1999), but sometimes are as high as 10 to $20 \mathrm{mg} / \mathrm{L}$ (Ryden and Lund, 1980). The precipitous drop in $\mathrm{NO}_{3}$ followed by relatively steady-state background values of 5-10 mg/L suggests that when $\mathrm{NO}_{3}$ was high (e.g. $>20 \mathrm{mg} / \mathrm{L}$ ), bacterial populations were established that fostered denitrification which resulted in decreases of $\mathrm{NO}_{3}$ to $\leq$ $5 \mathrm{mg} / \mathrm{L}\left(\mathrm{NO}_{3}-\mathrm{N}\right)$; Once $\mathrm{NO}_{3}$ concentration had decreased to low concentrations (i.e. $\left.<5 \mathrm{mg} / \mathrm{L}\right)$, however, the amount of remaining $\mathrm{NO}_{3}$ was insufficient to sustain bacterial populations needed to foster notable denitrification; if this is true, then the non-point source concentrations of 5 to 10 $\mathrm{mg} / \mathrm{L}$ are close to the threshold required to establish an effective population of denitrifying bacteria and are not appreciably reduced by denitrification.

The recovery of the FRA studied herein appears to have been enhanced by denitrification augmented by dilution involving regional groundwater and meteoric water. Isotopic compositions of $\mathrm{N}$ and $\mathrm{O}$ from nitrate provide strong evidence for the role of denitrification, but in the absence of measurements of groundwater $\mathrm{N}_{2} / \mathrm{Ar}$ ratio (to assess $\mathrm{N}_{2}$ as a product of denitrification; Wilson et al., 1990; Hiscock et al., 2011), it is difficult to precisely determine the 
proportional influence of denitrification relative to dilution. What is important to note is that denitrification did play a significant role in this bedrock structure-controlled aquifer.

\subsection{Comparison to Other FRA Nitrate Contamination Studies}

When fractured rock aquifers are exposed at the surface or are overlain by highlypermeable sediments, they are particularly vulnerable to nitrate contamination in agricultural areas (Levison and Novakowski, 2009; Hiscock et al., 2011; Tedd et al., 2014). This scenario is particularly applicable to the current study where bedrock structures at and very near to the surface $(<2 \mathrm{~m})$ directly transmitted nitrate or precursors from manure into the fractured rock aquifer. The detailed quarterly to annual monitoring of nitrate levels in groundwater from this fractured bedrock aquifer over a $\sim 12$ - year period enabled discrimination of point vs. non-point sources of nitrate, identification of the planar bedrock structures that control groundwater flow, and determination of the importance of lithotrophic denitrification as a likely cause of rapid declines of nitrate concentration in groundwater. In particular, a small ( $0.3 \mathrm{ha})$ nitrate pointsource in a ravine connected to the aquifer by bedding and foliation planes required $\sim 10$ years to return to background concentrations once the manure source had been remediated. Nitratecontaminated water was transmitted through flow paths controlled by bedding/foliation and fracture planes at a rate of $0.05 \mathrm{~m} /$ day, and decreasing nitrate at a rate of 5 to $9 \mathrm{mg} / \mathrm{L}\left(\mathrm{NO}_{3}-\mathrm{N}\right)$

per year is consistent with previous reports on $\mathrm{Mn}^{+2}$ - or $\mathrm{Fe}^{+2}$-mediated lithotrophic denitrification (Frind et al., 1990; Green et al., 2008; Jorgenson et al, 2009).

The response of fractured rock aquifers to nitrate loading is not well-understood, or at least there is some inconsistency in the literature. It is sometimes assumed that low amounts of organic matter in FRAs and the low surface area: volume ratio of most FRAs limit potential for 
denitrification, meaning that dilution via mixing with low- $\mathrm{NO}_{3}$ water is the main process by which nitrate will decrease once a source has been mitigated (e.g. Levison and Novakowski, 2009; Han et al., 2016). If this is the case in some FRAs, it is not the case in all, especially those containing pyrite, where in the absence of sufficient organic $\mathrm{C}, \mathrm{Mn}^{+2}$ and/or $\mathrm{Fe}^{+2}$ (often from pyrite) function as electron donors and denitrification occurs at rates comparable to those observed in the aquifer studied herein. Apparently, exposed surfaces on fracture and cleavage plans are sufficient to foster growth of denitrifying microbial populations (Tedd et al., 2014). Thus, what the existing research suggests is that FRAs containing pyrite in sufficient quantities have the potential to mitigate nitrate loading by denitrification, and that FRAs with little or no pyrite (or other source of $\mathrm{Mn}$ or $\mathrm{Fe}$ ) can be expected to undergo nitrate mitigation by mixing and dilution, but not denitrification to any significant extent. Given these observations, an apparent objective for FRA research would be a systematic study of nitrate-affected FRAs comprised of pyrite-bearing and pyrite-free rocks, ideally nearby aquifers with similar climate, biota, nitrate loading and other pertinent factors that would facilitate analysis of controls on denitrification..

In some parts of Prince Edward Island, Canada, where potato farms are abundant and approximately $20 \%$ of wells exceed the $10 \mathrm{mg} / \mathrm{L}$ nitrate standard, Zebarth et al. (2015) had to use long-term monitoring of nitrate levels in streams as a proxy for groundwater nitrate concentrations at the watershed scale, rather than domestic or monitoring well data. Through a comprehensive hydrogeological characterization of the surficial materials and bedrock, Zebarth et al. (2015) determined that groundwater flow in the vadose zone was dictated by the matrix porosity of the glacial till and underlying sandstone whereas that in the phreatic zone was controlled by a transmissive fracture network. They also discovered that nitrate is sequestered in the rock or till matrix and takes time to diffuse out into the surficial and aquifers, significantly 
delaying the time from BMP implementation to aquifer and surface water recovery, which may take decades.

Withers et al. (1998) and Gooddy et al. (1998) monitored nitrate concentrations vs time (1975 - 1982) in pore water from unsaturated zone boreholes near or beneath unlined manure lagoons in the United Kingdom and concluded that the nitrate and bacterial contamination occurred via fracture flow. Mechanical disturbances of the manure pit bottom with heavy equipment eventually caused pulses of high nitrate concentration in this unsaturated zone pore water. Further work by Gooddy et al. $(1998 ; 2001 ; 2002)$ on boreholes beneath the same manure pit, determined that pore water and fracture surfaces were contaminated to depths of $30 \mathrm{~m}$ by nitrate and chloride after 18 years of monitoring.

\subsection{Applicability of Aquifer Characterization Methodology}

The integrated method applied in this study for fractured bedrock aquifer characterization is applicable not only to nitrate contamination of groundwater but also to fate and transport of naturally-occurring radionuclides (Kim et al., 2014) and arsenic (Ryan et al., 2011; 2013) and presumably would be suitable to study of other contaminants in FRAs. This approach contains a "toolbox" of physical and chemical methods to choose from and adapt based on the particular bedrock aquifer, which, in Vermont, is complexly-deformed and metamorphosed to varying degrees. Detailed bedrock geologic mapping and cross sections are the foundation upon which these studies are built, so that the three-dimensional relationship of ductile and brittle structures and lithologies are well-defined first. Each successive step in aquifer characterization builds upon the previous one. The chemical methods are integrated into the model after the physical methods have been completed. 
The comprehensive analysis of well logs integrates depth to bedrock, well depth, well elevation, and surficial material characteristics with surficial geologic maps to construct a bedrock surface contour map and/or isopach map that completes the three-dimensional geologic framework. Bedrock basins and ridges that may influence groundwater flow are identified during this stage once the geometry of surficial deposits is known. In a thrust-faulted scenario, Kim et al. (2014) used well depths, yields, and lithologic well logs to define the complex geometry of a folded thrust at depth, which separates a low-yielding metamorphic rock (phyllite) aquifer of the hanging wall from a productive carbonate sedimentary aquifer from the foot wall; this entire study was built on detailed bedrock mapping.

EMI surveys are often ideal for delineating linear trends in the bedrock aquifer that correlate exactly with the planar structural trends defined by bedrock mapping, but are not visible in a landscape covered to varying depths with surficial material. In addition to the EMI data shown for this study, an EMI survey conducted on a nearby dairy farm and also in the Waits River Formation, defined buried map-scale fold structures in a pasture (Ruksznis et al., 2012), in addition to fracture zones. With data from bedrock mapping and EMI in hand, borehole camera survey interpretations have critical context. At his point, fracture flow pathways can be determined from equilibrium static water levels from bedrock wells that are integrated with detailed bedrock maps, EMI surveys, and bedrock surface contour maps and/or isopach maps as a base. 


\section{Conclusions}

1. In 2001, elevated nitrate levels ranging from 12 to $34 \mathrm{mg} / \mathrm{L} \mathrm{NO}_{3}-\mathrm{N}$ were discovered in groundwater from 10/19 (53\%) domestic bedrock wells adjacent to a large dairy farm in central Vermont.

2. Long-term plots and contours of nitrate vs. time for bedrock wells showed "little/no", "moderate", and "large" change patterns that were spatially separable.

3. Based on comprehensive physical and chemical aquifer characterization, the metasedimentary bedrock aquifer is strongly anisotropic and groundwater flow is controlled by planar structures such as fractures, bedding/foliation, and basins and ridges in the bedrock surface; in fact, migration of the ravine-derived nitrate plume could not have been predicted or comprehended without the detailed aquifer characterization.

4. Integration of the nitrate vs. time data and the physical and chemical aquifer characterization suggest two nitrate sources: a point source emanating from a waste ravine and a non-point source that encompasses the surrounding fields. Once removed, the point source of $\mathrm{NO}_{3}$ (manure deposited in a ravine) was exhausted and $\mathrm{NO}_{3}$ dropped from $>30 \mathrm{mg} / \mathrm{L}$ to $<10 \mathrm{mg} / \mathrm{L}$ after $\sim 10$ years; however, persistence of $\mathrm{NO}_{3}$ predominantly in the 3 to $8 \mathrm{mg} / \mathrm{L}$ range (regional background) appears to reflect the long term consistent flux of nitrates, likely from nutrients applied to the farm fields surrounding the ravine over the years predating and including this study.

5. Inferred groundwater flow rates from the waste ravine to either moderate change wells in basin 2 or to the shallow bedrock zone beneath the large change wells are $0.05 \mathrm{~m} / \mathrm{day}$, well within the range of published bedrock aquifer flow rates. 
6. CFC 113 average recharge ages for groundwater range from 17-22 years and suggest a relatively well-mixed system with modern, ongoing recharge.

7. Supersaturated levels of CFC 11 and 12 in groundwater sampled from wells in the field area are consistent with derivation of these CFCs from refrigerators formerly buried in the waste ravine, where the CFCs were delivered to groundwater through a combination of bedding $/ \mathrm{S}_{1}$ foliation and the dominant fracture sets - this is likely the same path taken by nitrate infiltrating the aquifer from the ravine.

8. Enrichment of ${ }^{15} \mathrm{~N}$ and ${ }^{18} \mathrm{O}$ in nitrate is consistent with lithotrophic denitrification of $\mathrm{NO}_{3}$ in the presence of dissolved Mn (and possibly Fe too). Once the ravine point-source was removed, denitrification and dilution were responsible for the down-gradient decrease of nitrate in this bedrock aquifer. Denitrification was apparently most influential when $\mathrm{NO}_{3}-$ $\mathrm{N}$ was $>10 \mathrm{mg} / \mathrm{L}$.

9. The physical and chemical methods of aquifer characterization applied in this study are not only applicable to nitrate contamination of FRA groundwater, but also to the study of radionuclides and arsenic. Any study of complexly-deformed and metamorphosed FRAs could benefit from this multidisciplinary approach, particularly with the foundation of detailed bedrock geologic mapping.

\section{Acknowledgements}

The authors would like to thank: Editor Damia Barcelo and four anonymous reviewers for insightful and thoughtful reviews, the Fairmont Farm and the surrounding homeowners for access to their land and wells over the duration of this study; the Vermont Dept. of Environmental Conservation and Agency of Agriculture labs for geochemical analyses; Don 
Maynard of the Johnson Company for technical assistance with monitor well installation and well sampling, Jeff Hoffer of Hoffer Consulting, Inc. for borehole camera surveys, Jim Doolittle and the National Resource Conservation Service for the EMI surveys; and the Environmental Protection Agency- Section 319 and the U.S. Geological Survey STATEMAP programs for funding. 


\section{References}

Best, A., Arnaud, E., Parker, B., Aravena, R. and Dunfield, K. (2015), Effects of Glacial Sediment Type and Land Use on Nitrate Patterns in Groundwater. Groundwater Monitoring \& Remediation, 35. 68-81.

Bohlke, J.K. and Denver, J.M., 1995, Combined use of groundwater dating, chemical, and isotopic analyses to resolve the history and fate of nitrate contamination in two agricultural watersheds, Atlantic coastal plain, Maryland: Water Resources Research, 31 (9). 2319-2339.

Boy-Roura M., Nolan, B.T., Menció, A., and Mas-Pla, J., 2013, Regression model for aquifer vulnerability assessment of nitrate pollution in the Osona region (NE Spain). Journal of Hydrology, 505, $150-162$.

Canter, L.W., 1997, Nitrates in Groundwater: CRC Press LLC, 263.

Carle, S.F., Tompson, A. and Esser, B.K., 2004. Modeling basin scale nitrate transport considering alluvial and biogeochemical heterogeneity: Geological Society of America Abstracts with Programs. 36. 5. 394.

Chapman, S., Parker, B., Cherry, J. Munn, J., Malenica, A., Ingleton, R., Jiang, Y, Padusenko, G., and Piersol, J., 2015. Hybrid Multilevel System for Monitoring Groundwater Flow and Agricultural Impacts in Fractured Sedimentary Bedrock. Groundwater Monitoring and Remediation, 35. 55-67.

Cook, P. G. and Herczeg, A. L. (Eds.), 2000, Environmental Tracers in Subsurface Hydrology: Springer US. 529.

Environmental Isotope Lab, University of Waterloo:

http://www.uweilab.ca/web/eil/cat/expertise_page/index, accessed 4/19/16.

Ericksen, G.E., 1981, Geology and origin of the Chilean nitrate deposits: U.S. Geological Survey Professional Paper 1188, 37.

Faure, S., Tremblay, A., and Angelier, J., 1996, States of intraplate stress and tectonism of northeastern America since Cretaceous times, with particular emphasis on the New EnglandQuebec igneous province: Tectonophysics, 255, 111-134.

Frind, E.O., Duynisveld, W.H.M., Strebel, O., and Bottcher, J., 1990, Modeling of Multicomponent Transport with Microbial Transformation in Groundwater- The Fuhrberg Case. Water Resources Research, 26, 1707-1719.

Gooddy D. C., Withers, P. J .A., McDonald, H. G., and Chilton, P. J., 1998, Behaviour and impact of cow slurry beneath a storage lagoon: II, Chemical composition of chalk porewater after 18 years. Water, Air and Soil Pollution 107 (1/4), 5172. 
Gooddy, D. C., Hughes, A. G., Williams, A. T., Armstrong, A. C., Nicholson, R. J. and Williams, J. R., 2001, Field and modelling studies to assess the risk to UK groundwater from earth-based stores for livestock manure, Soil Use and Management 17, 128-137.

Gooddy, D. C., Clay, J .W., and Bottrell, S. H., 2002, Redox-driven changes in pore-water chemistry of the Chalk unsaturated zone beneath unlined cattle slurry lagoons, Applied Geochemistry, 17, 7, 903-921.

Gourley, S.H., Wheeler, B., Howard, G., DeKett, R., 2004, Soil Survey of Washington County, Vermont: U.S. Dept. of Agriculture, National Resource Conservation Service, 401 p.

Hall, L.M., 1956, The Geology of the St. Johnsbury Quadrangle, Vermont and New Hampshire: Vermont Geological Survey Bulletin \#13, 105. map scale 1:62,500.

Hiscock K.M., Iqbal T., Feast N.A. and Dennis P.F., 2011, Isotope and reactive transport modelling of denitrification in the Lincolnshire Limestone aquifer, eastern England. Quarterly Journal of Engineering Geology and Hydrogeology 44, 93-108, doi: 10.1144/1470-9236/08-110

Johnson, C.W., 1998, The Nature of Vermont, University Press of New England. 354.

Kauffman, L.J., Baehr, A.L., Ayers, M.A., and Stackelberg, P.E. 2001. "Effects of Land use and Travel Time on the Distribution of Nitrate in the Kirkwood-Cohansey Aquifer System in Southern New Jersey." Water-Resources Investigations - U.S. Geological Survey: 49.

Kendall, C. (1998): Tracing nitrogen sources and cycling in catchments. In: Kendall, C. \& McDonnell, J.J. (eds.): Isotope Tracers in Catchment Hydrology. Elsevier, Amsterdam. 519576.

Kim, J., Gale, M., King, S. M., Orsi, C. M., and Pascale, L., 2003, Bedrock Geologic Map of the Montpelier Quadrangle: Vermont Geological Survey Open File Map VG03-1, scale 1:24,000, 1 sheet.

Kim, J., Gale, M., McMillan, M., Zolkos, S., and Springston, G., 2010, Bedrock Geologic Map of the Town of Craftsbury, Vermont: Vermont Geological Survey Open File Map, scale $1: 24,000,3$ plates.

Kim, J. and Ruksznis, A., 2011a, Bedrock Geologic Map of the Plainfield Quadrangle, Washington County, Vermont: Vermont Geological Survey Open File Map VG11-3, scale $1: 24,000,2$ plates.

Kim, J., Klepeis, K., Ryan, P., Gale, M., McNiff, C., Ruksznis, A., and Webber, J., 2011b, A Bedrock Transect Across the Champlain and Hinesburg Thrusts in West-Central Vermont: Integration of Tectonics with Hydrogeology and Groundwater Chemistry: in West, D., editor, New England Intercollegiate Geological Conference: Guidebook for Field Trips in Vermont and adjacent New York, 103rd Annual Meeting, Middlebury, Vermont, Trip B1, p. B1-1 - B1-35. 
Kim, J.J., Ryan, P., Klepeis, K., Gleeson, T., North, K., Davis, L., Bean, and Filoon, J., 2014, Tectonic evolution of a Paleozoic thrust fault influences the hydrogeology of a fractured rock aquifer, northeastern Appalachian foreland: Geofluids, doi:10.1111/gfl.12076.

Kim, J., Gale, M., Springston, G., Koteas, C., Defelice, C., and Saitta, N., 2015, Bedrock Geologic Map of the Southern Two-Thirds of the Woodbury Quadrangle, Vermont, Washington County, Vermont: Vermont Geological Survey Open File Report VG2015-2, scale 1:24,000, 1 plate.

Korom, S.F., Schuh, W.M., Tesfay, T., and Spencer, E.J., 2012, Aquifer denitrification and in situ mesocosms: modeling electron donor contributions and measuring rates: Journal of Hydrology, 432/433, 112-126, doi:10.1016/j.jhydrol.2012.02.023, 2012.

Kozuskanich, J.C., Novakowski, K.S., Anderson, B.C., Crowe, A.S. and Balakrishnan, B.K., 2014, Anthropogenic impacts on a bedrock aquifer at the village scale: Ground Water. 52. 3. 474-486.

Krásný, J., Sharp, J.M., Jr., and Troeger, U., 2014, IAH commission on Hardrock Hydrogeology (HyRoC): Past and present activities, future possibilities. In Fractured Rock Hydrogeology, ed. J.M. Sharp. 1-12. International Association of Hydrogeologists Selected Papers. 20, CRC Press.

Levison, J. and Novakowski, K. (2009) The impact of cattle pasturing on groundwater quality in bedrock aquifers having minimal overburden. Hydrogeology Journal, 17: 559-569.

Landig, F., Fenton, O., Bons, P., Hennessy, D., Richards, K., and Blum, P., 2011, Estimation of nitrate discharge in a fractured limestone aquifer below a dairy farm in Ireland: The International Association of Hydrological Sciences. 342. 469-472.

Mariotti, A., Landreau, A. \& Simon, B. (1988) Vulnerability of shallow groundwater and drinking water to nitrate in the United States. Environmental Science and Technology, 40, 78347840 .

McHone, J.G., 1978, Distribution, orientations, and ages of mafic dikes in central New England: Geological Society of America Bulletin, 89, 1645-1655.

Metcalf, M.J. and Robbins, G.A., 2013, Natural Buffering of Contaminants Related to Development in Fractured Rock. Groundwater Monitoring \& Remediation, v. 33, no. 4: 89-99.

Muldoon, M.A., Simo, J. and Bradbury, K,, 2001, Correlation of hydraulic conductivity with stratigraphy in a fractured-dolomite aquifer, northeastern Wisconsin, USA. Hydrogeology Journal, 9, 570-583

Nolan, B.T. and Hitt, K.J. 2006a. Vulnerability of shallow groundwater and drinking-water wells to nitrate in the United States. Environmental Science and Technology. Vol. 40, no. 24. 78347840 . 
Nolan, B.T. and Hitt, K.J., 2006b, 15N isotope biogeochemistry and natural denitrification process in groundwater: application to the chalk aquifer of northern France. Geochimica et Cosmochimica Acta, 52, 1869-1878.

Paerl, H.W., Gardner, W.S., McCarthy, M.J., Otten, T.G., Peierls, B.L.,Rossignol, K.L., and Wilhelm, S.W. (2015). Mitigating Harmful Cyanobacterial Blooms in a Human- and Climatically-Impacted World. IAGLR $58^{T H}$ Annual Conference on Great Lakes Research, Burlington Vermont, Abstracts. 4(4). 988-1012.

Pauwels, H. Foucher, J., and Kloppmann, W. 2000. "Denitrification and Mixing in a Schist Aquifer; Influence on Water Chemistry and Isotopes." Chemical Geology 168 (3-4): 307-324.

Ratcliffe, N.M., Stanley, R.S, Gale, M.H., Thompson, P.J., and Walsh, G.J., 2011, Bedrock Geologic Map of Vermont: U.S. Geological Survey Scientific Investigations Map 3184, 3 sheets, scale $1: 100,000$.

Rudolph, D.L., 2015, Groundwater Quality Within the Agricultural Landscape: Assessing the Performance of Nutrient BMPs. Groundwater Monitoring \& Remediation, 35: 21-22.

Ruksznis, A., Kim, J., Klepeis, K., and Webb, L., 2012, Integration of Structural Analysis, EMI and GPR Surveys, and Hydrogeology in the Plainfield Quadrangle: Geological Society of America, Abstracts with Programs, 44, (2), 98.

Ryan, P.C., Kim, J., Wall, A.J., Moen, J.C., Corenthal, L.G., Chow, D.R., Sullivan, C.M., Bright, K.S., 2011, Ultramafic-derived arsenic in a fractured bedrock aquifer: Applied Geochemistry, (26), 444-457.

Said, A.M. 2007. "Effects of Cesspool Systems on Groundwater Quality of Shallow Bedrock Aquifers in the Recharge Area of Wadi Fatimah, Western Arabian Shield, Saudi Arabia." Journal of Environmental Hydrology 15 (8): 11.

Sanford, W.E. and Pope, J.P., 2013, Quantifying Groundwater's Role in Delaying Improvements to Chesapeake Bay Water Quality: Environmental Science and Technology, 47, 13330-13338.

Singhal, B.B.S. and Gupta, R.P., 2006, Applied Hydrogeology of Fractured Rocks: Springer, Heidelberg, 408.

Stewart, D. and MacClintock, P., 1970, Surficial Geologic Map of Vermont, Vermont Geological Survey Map, 1 plate, scale 1:250,000.

Tedd, K.M., Coxon, C.E., Misstear, B.D.R., Daly, D., Craig, M., Mannix, A., and Hunter Williams, N.H., 2014, An Integrated Pressure and Pathway Approach to the Spatial Analysis of Groundwater Nitrate: A Case Study from the Southeast of Ireland: Science of the Total Environment, 476-477, 460-476. 
Telford, W.M., Geldhart, L.P., Sheriff, R.E., and Keys, D.A., 1976, Applied Geophysics, Cambridge University Press, Cambridge, 860.

The Johnson Company, 1995, Montpelier Springs: Recharge Area Calculations and Maps, 4 p.

Tritium Laboratory, Advice on Sampling for CFCs, http://www.uweilab.ca/web/eil/cat/books/books-1149124725170, accessed 4/19/16

U.S. Geological Survey, General facts and Concepts About Ground Water, Sustainability of Ground-Water Resources- Circular 1186, 6 p., http://pubs.usgs.gov/circ/circ1186/html/gen_facts.html, accessed 4/19/16

U.S. Geological Survey, Office of Water Quality, Water-Quality Information, Water Hardness and Alkalinity.

http://water.usgs.gov/owq/hardness-alkalinity.html, accessed 4/19/16

Venterea, R.T. and D.E. Rolston. 2000. Nitric and nitrous oxide emissions following fertilizer application to agricultural soil: Biotic and abiotic mechanisms and kinetics. J. Geophys. Res.Atm. 105:15117-15129.

Ward MH, deKok TM, Levallois P, Brender J, Gulis G, Nolan BT, VanDerslice J. 2005 b. Workgroup report: Drinking-water nitrate and health--recent findings and research needs. Environ Health Perspect 113(11):1607-1614.

Wilson, G.B., Andrews, J.N. and Bath, A.H., 1990, Dissolved gas evidence for denitrification in the Lincolnshire Limestone groundwaters, Eastern England. Journal of Hydrology, 113, 51-60.

Withers P.J.A., Macdonald H.G., Smikth, K.A. and Chumley C.G., 1998, Behaviour and impact of cow slurry beneath a storage lagoon: 1, Groundwater contamination 1975-1982, Water Air and Soil Pollution 107, (1/4), 35-49.

Worthington, S.R., 2015, Characteristics of channel networks in unconfined carbonate aquifers: Geological Society of America Bulletin, 127: 759-769.

Walsh, G. J., Kim, J., Gale, M. H., and King, S. M., 2010, Bedrock geologic map of the Montpelier and Barre West quadrangles, Washington and Orange Counties, Vermont: U.S. Geological Survey Map, scale 1:24,000, 36, 1 sheet.

Ward, S., and Pope, J.P. 2013. Quantifying Groundwater's Role in Delaying Improvements to Chesapeake Bay Water Quality. Environmental Science \& Technology 201347 (23), 1333013338

Wick, K., Heumesser, C., and Schmid, E., 2012, Groundwater nitrate contamination: Factors and indicators: Journal of Environmental Management. 111. 178-186. 
Williard, Karl W. J., David R. Dewalle, and Pamela J. Edwards. 2005. "Influence of Bedrock Geology and Tree Species Composition on Stream Nitrate Concentrations in Mid-Appalachian Forested Watersheds." Water, Air, \& Soil Pollution 160 (1-4): 55-76.

Zebarth, B.J., Danielescu, S., Nyiraneza, J. Ryan, M. Cathryn., Jiang, Y., Grimmett, and Burton, D.L., 2015b, Controls on Nitrate Loading and Implications for BMPs Under Intensive Potato Production Systems in Prince Edward Island, Canada: Groundwater Monitoring and Remediation, 35. 111. 30-42. 


\section{Figure Captions}

Figure 1 Base map of the dairy farm area. The main barn yard and production area are located in the lower right (southeast) and labeled as "dairy farm". Topographic contours in yellow with a contour interval $=6 \mathrm{~m}$.

Figure 2 Location of the study area (red square) and the Town of East Montpelier (yellow rectangle) on a map of Vermont's bedrock belts (modified from Kim et al., 2011b). Inset map shows Vermont in the context of the northeastern United States.

Figure 3 Nitrate concentration (mg/L) vs. time patterns for A) "Little/No Change" wells (Type I), B) "Moderate Change" wells, and C) "Large Change' wells (fields for each well type shaded in transparent yellow); D) Nitrate vs. time pattern for spring 1343 (s1343) shown with that of w1039 for comparison.

Figure 4 Locations of nitrate pattern types shown on base map of the field area. Waste ravine is the brown polygon. Topographic contours in yellow with a contour interval $=6 \mathrm{~m}$.

Figure 5 Nitrate concentration $(\mathrm{mg} / \mathrm{L})$ vs. time patterns of wells for the six-month period from May 2005 to October 2005.

Figure 6 Contoured nitrate concentrations $(\mathrm{mg} / \mathrm{L})$ for the following time slices: A) Time I- 1031-2000, B) Time II- 10-22-2002, C) Time III- 12-09-2004, D) Time IV- 11-04-2005, E) Time V- 4-03-2007, and F) Time VI- 2-10-2009.

Figure 7 Frequency - azimuth rose diagrams and equal area nets for bedding $/ S_{1}$ foliation $(A+B)$ and fracture $(C+D)$ sets (Georient software, Holcombe, 1996). Equal area nets plot poles to planes for foliations and fractures. Thematic block diagram of bedrock structures shown in Figure 7E.

Figure 8 Contour map of the bedrock surface in meters (contour interval $=6 \mathrm{~m}$ ). Locations of significant features are labeled and described in the text. Overburden thicknesses $(\mathrm{m})$ at each well or spring are shown with red labels.

Figure 9 A) Map of the field area with location of EMI survey (yellow rectangle). Black arrows show the azimuths of EMI anomalies from B, which are also plotted on the frequency-azimuth rose diagram inset (Georient software, Holcombe, 1996). B) Contoured EMI data from the survey area with data from horizontal dipole orientations above and vertical dipole orientation below; northern end of the waste ravine is labeled. The azimuths of the three linear anomaly segments correlate with the strikes of bedding/ $\mathrm{S}_{1}$ foliation, dominant $\mathrm{E}-\mathrm{W}$ fracture set, and subordinate NW trending fracture set. 
Figure 10 A) Potentiometric surface contour map (meters above sea level; contour interval = $6 \mathrm{~m}$ ). Static water level at each well (meters above sea level) shown with blue numbers. Ground surface elevation of each well (meters above sea level) shown with red numbers. Light blue arrows show flow directions for groundwater in the bedrock aquifer.

Figure 11 A) Borehole camera photo from well 1070 at a depth of $16.5 \mathrm{~m}$ showing water (silvery-white) entering the borehole from the right side along dipping planes, which are likely $\mathrm{S}_{1}$ foliation/bedding (borehole is $0.15 \mathrm{~m}$ in diameter). B) Borehole camera photo from well 1068 at a depth of $32.9 \mathrm{~m}$ showing water squirting into the borehole from the left (behind pump hose) along a dipping likely $S_{1}$ foliation/bedding plane. C) Borehole camera photo from well 1063 at a depth of $41.1 \mathrm{~m}$ showing a cave in the borehole; whereas the cave encompasses the full field of view, the $0.15 \mathrm{~m}$ diameter borehole only takes up the lower left side.

Figure 12. Nitrogen and oxygen isotope data for nitrate sampled in August 2005. Compositional fields and denitrification trend shown in Figure 11A are from Kendall (1998). Figures 11B and $11 \mathrm{C}$ plot nitrate concentration vs. nitrogen and oxygen isotopic values. 11B shows denitrification and mixing trends of Mariotti et al. (1988) as presented in Kendall (1998). 11C shows expected curves for denitrification and dilution (by mixing) in a plot of NO3 vs. $\delta 18 \mathrm{O}$.

Figure 13 The conceptual model for nitrate contamination in the field area involves point (ravine) and non-point (field) sources. This figure integrates bedrock surface features from Figure 7; bedrock structural data from figures 8 and 9; and bedrock aquifer flow directions from Figure 10. Solid magenta arrows show that groundwater flow from the ravine is first constrained by bedding/S1 and then by the dominant fracture set. The dashed magenta arrow shows a likely route for ground water to flow from the ravine to the northwest; this first involves flow along bedding/ $\mathrm{S}_{1}$ followed by topographically-driven flow into basin 2 . See text for explanation.

\section{Tables}

Table 1 CFC data.

\section{Data Repository}

DR-1 Data for wells in the field area that includes Total Depth (m), Depth to Bedrock (DTBR) in meters, Casing Depth (m), Well Elevation ASL (above sea level (m)), Well Stickup (casing stickup (m) above ground surface), Static Water Level measurements (meters above sea level) that were taken on 9/21/05 and 11/3/05, and the Bedrock Surface Elevation (meters above sea level) at each well or spring.

DR-2 Nitrate data for wells in the field area. Sampling periods outlined in black were the time intervals used for nitrate contours in Figure 6. 


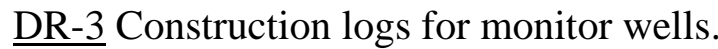

DR-4 Logs for domestic wells that were surveyed using the borehole camera.

DR-5 Groundwater geochemical data for wells in the field area. An * indicates that the value that follows is the detection limit.

DR-6 Nitrogen and oxygen isotope data. 
Table 1. Recharge ages (in years before present) for two sample periods in 2005 as determined by CFC analysis. Given the lack of contamination in CFC-113 dates relative to CFC-11 and CFC-12, CFC-113 dates were used to assess groundwater ages (right column). Ages could not be determined in cases where samples were supersaturated (SS).

\begin{tabular}{|c|c|c|c|c|c|c|}
\hline Month Sampled & Well ID & Replicate & CFC-11 & CFC-12 & CFC-113 & AGE \\
\hline \multirow[t]{3}{*}{ July } & MW2D & 1 & SS & SS & $19 \pm 2$ & \\
\hline & & 2 & SS & SS & $19 \pm 2$ & $19 \pm 2$ \\
\hline & & 3 & SS & SS & $19 \pm 2$ & \\
\hline \multirow[t]{3}{*}{ November } & MW2D & 1 & SS & SS & $17 \pm 2$ & \\
\hline & & 2 & SS & SS & $17 \pm 2$ & $17 \pm 2$ \\
\hline & & 3 & SS & SS & $17 \pm 2$ & \\
\hline \multirow[t]{3}{*}{ July } & 1039 & 1 & SS & SS & $18 \pm 2$ & \\
\hline & & 2 & SS & SS & $18 \pm 2$ & $18 \pm 3$ \\
\hline & & 3 & SS & SS & $19 \pm 2$ & \\
\hline \multirow[t]{3}{*}{ November } & 1039 & 1 & SS & SS & $17 \pm 2$ & \\
\hline & & 2 & SS & SS & $17 \pm 2$ & $17 \pm 2$ \\
\hline & & 3 & SS & SS & $17 \pm 2$ & \\
\hline \multirow[t]{3}{*}{ July } & 1063 & 1 & SS & SS & $19 \pm 2$ & \\
\hline & & 2 & SS & SS & $19 \pm 2$ & $19 \pm 2$ \\
\hline & & 3 & SS & SS & ND & \\
\hline \multirow[t]{3}{*}{ November } & 1063 & 1 & SS & SS & $18 \pm 2$ & \\
\hline & & 2 & SS & SS & $17 \pm 2$ & $17 \pm 3$ \\
\hline & & 3 & SS & SS & $17 \pm 2$ & \\
\hline \multirow[t]{3}{*}{ July } & 1065 & 1 & SS & SS & $19 \pm 2$ & \\
\hline & & 2 & SS & SS & $19 \pm 2$ & $19 \pm 2$ \\
\hline & & 3 & SS & SS & $19 \pm 2$ & \\
\hline \multirow[t]{3}{*}{ November } & 1065 & 1 & SS & SS & $18 \pm 2$ & \\
\hline & & 2 & SS & SS & $18+2$ & $18+2$ \\
\hline & & 3 & SS & SS & $18+2$ & \\
\hline \multirow[t]{3}{*}{ July } & 1068 & 1 & SS & 15 & $22 \pm 2$ & \\
\hline & & 2 & 19 & 13 & $22 \pm 2$ & $22 \pm 2$ \\
\hline & & 3 & SS & 12 & $22 \pm 2$ & \\
\hline \multirow[t]{3}{*}{ November } & 1068 & 1 & SS & SS & $21 \pm 2$ & \\
\hline & & 2 & SS & SS & $21 \pm 2$ & $21 \pm 2$ \\
\hline & & 3 & SS & 17 & $21 \pm 2$ & \\
\hline \multirow[t]{3}{*}{$\overline{\text { July }}$} & 1070 & 1 & 15 & SS & $21 \pm 2$ & \\
\hline & & 2 & 19 & SS & $21 \pm 2$ & $21 \pm 3$ \\
\hline & & 3 & 19 & SS & $22 \pm 2$ & \\
\hline \multirow[t]{3}{*}{ November } & 1070 & 1 & 19 & 13 & $19 \pm 2$ & \\
\hline & & 2 & 18 & SS & $18 \pm 2$ & $19 \pm 3$ \\
\hline & & 3 & 19 & 19 & $19 \pm 2$ & \\
\hline
\end{tabular}



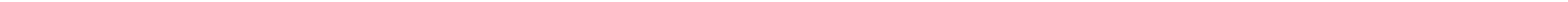
Figure 2

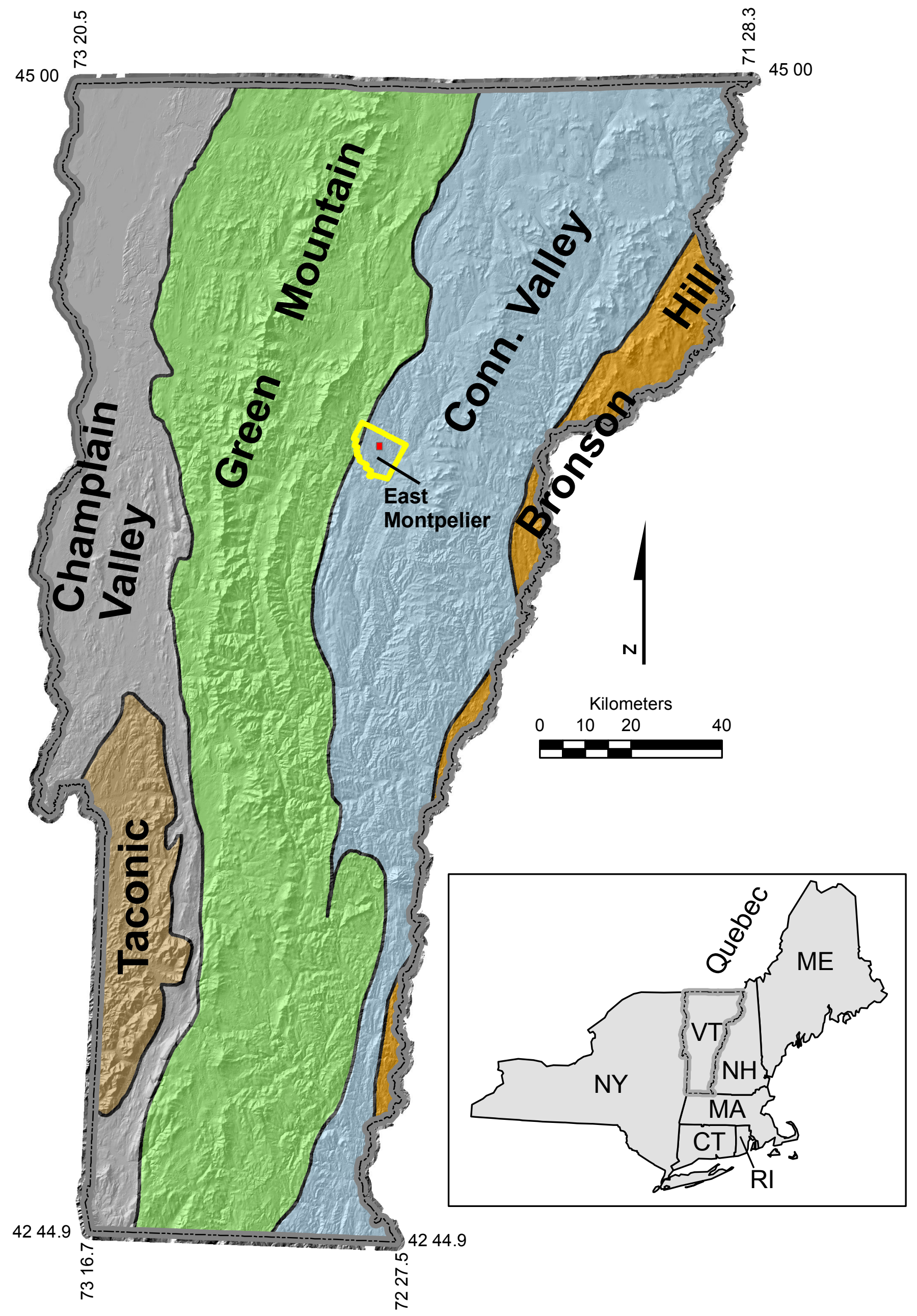



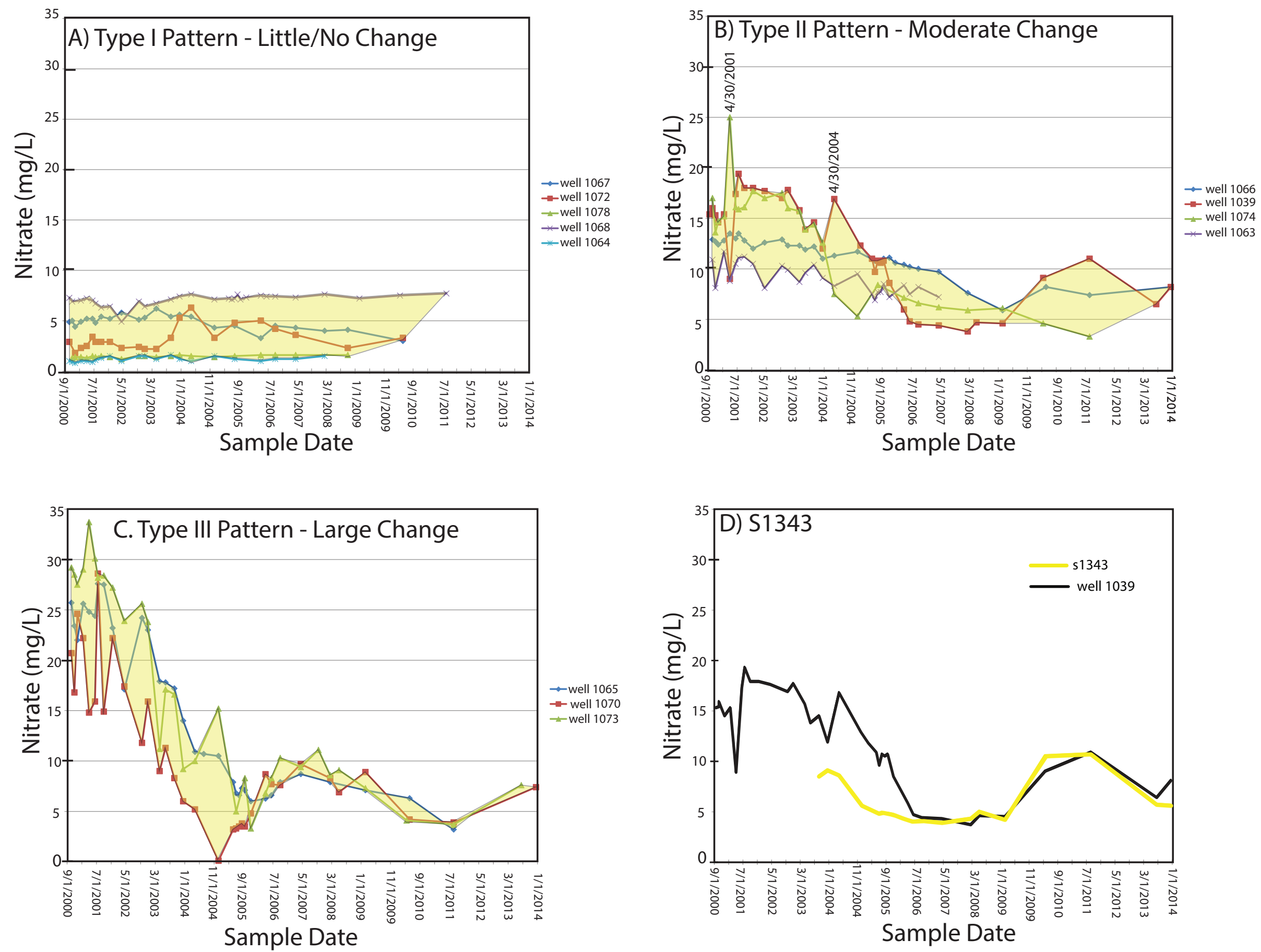


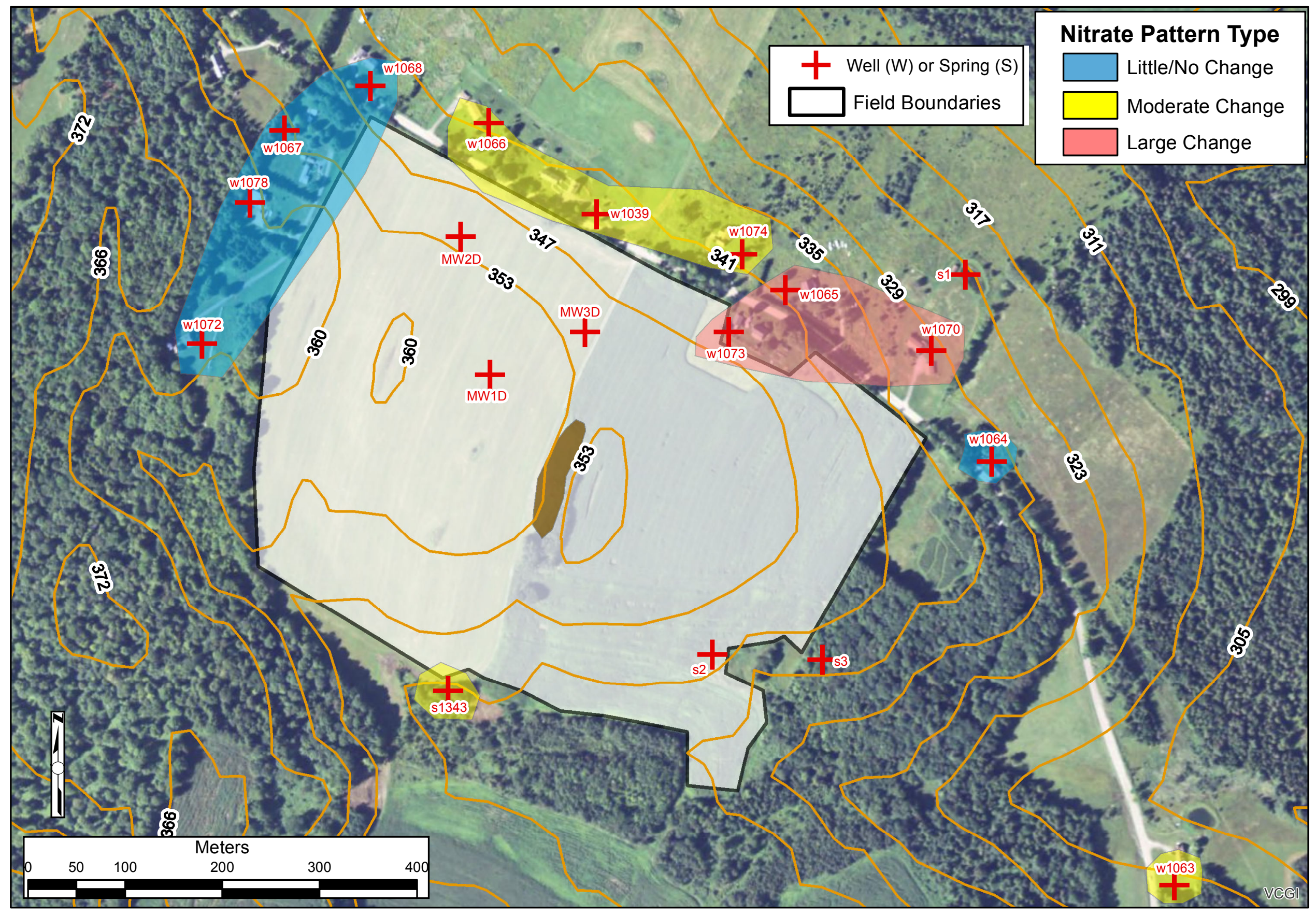




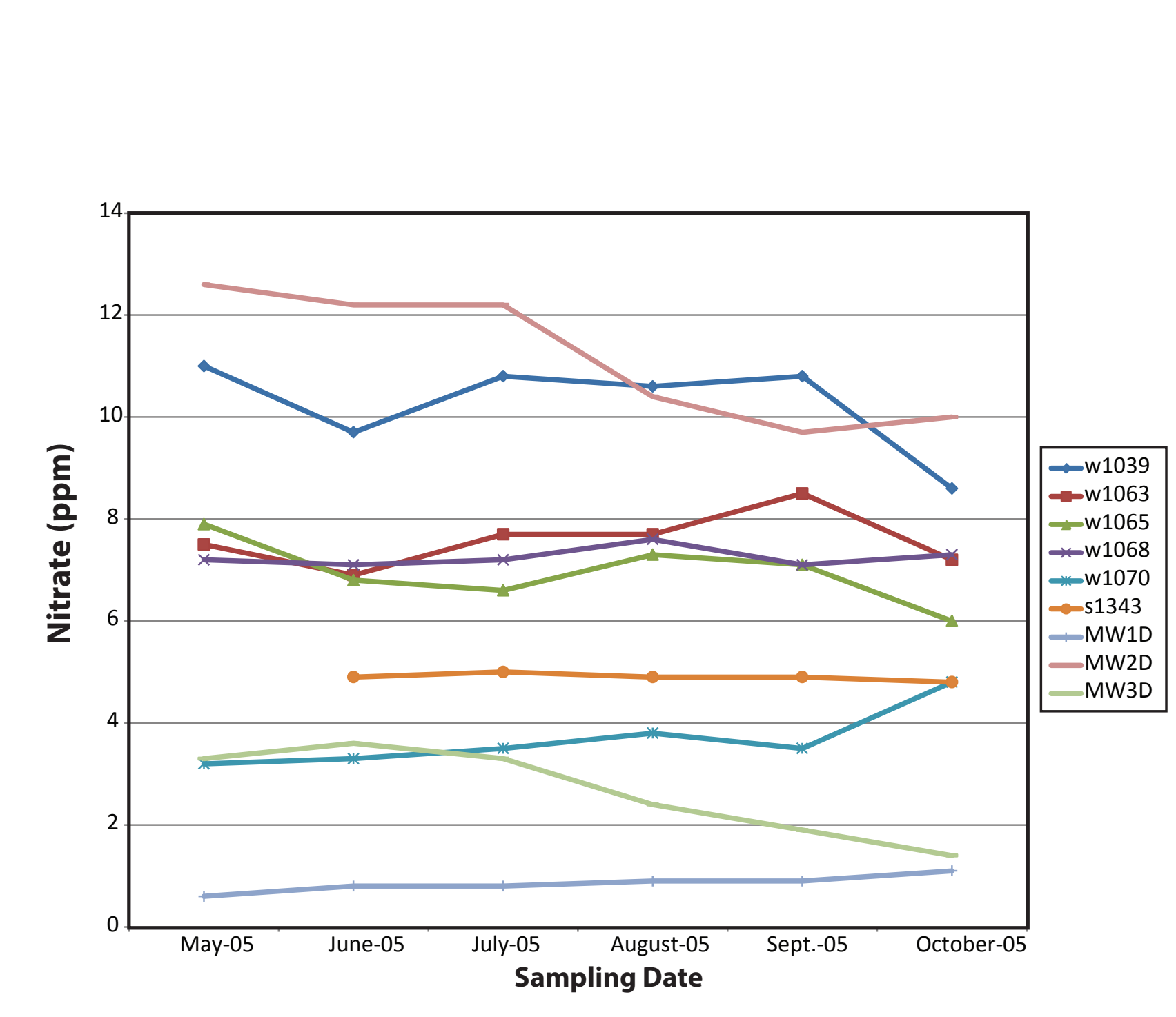

Figure 5

\section{Sampling Date}

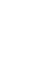

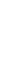




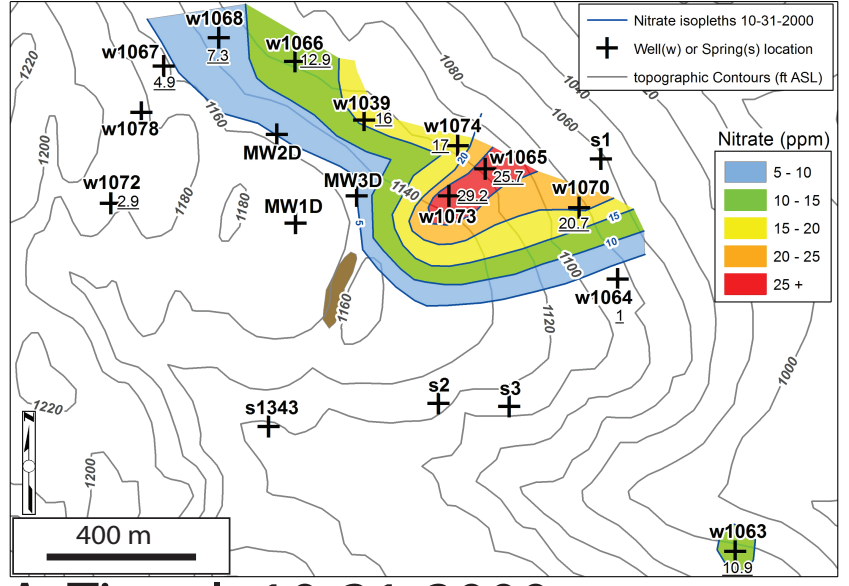

A. Time I- 10-31-2000

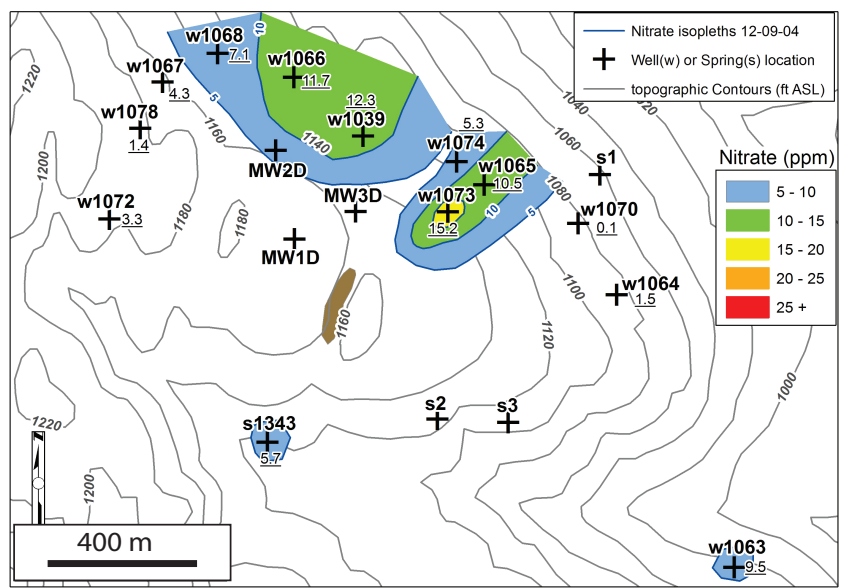

C. Time III- 12-09-2004

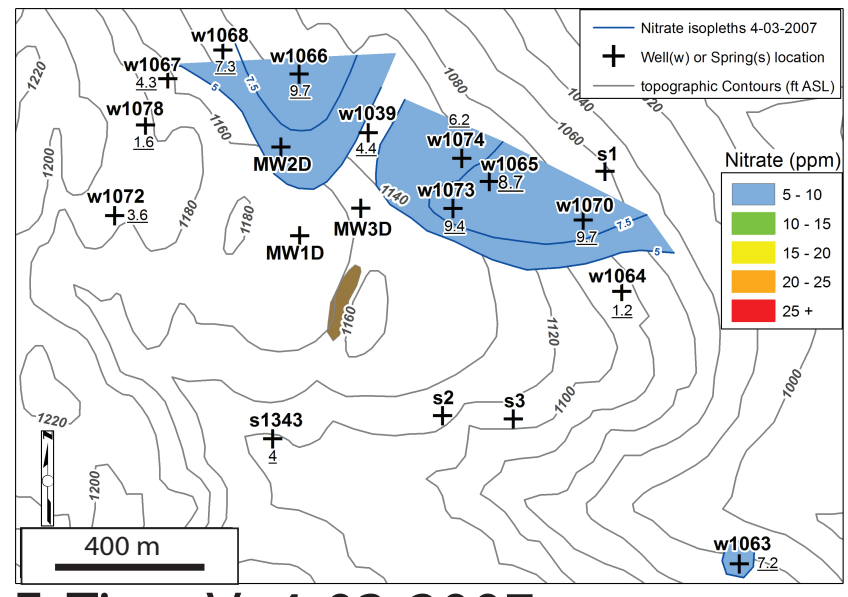

E. Time V-4-03-2007

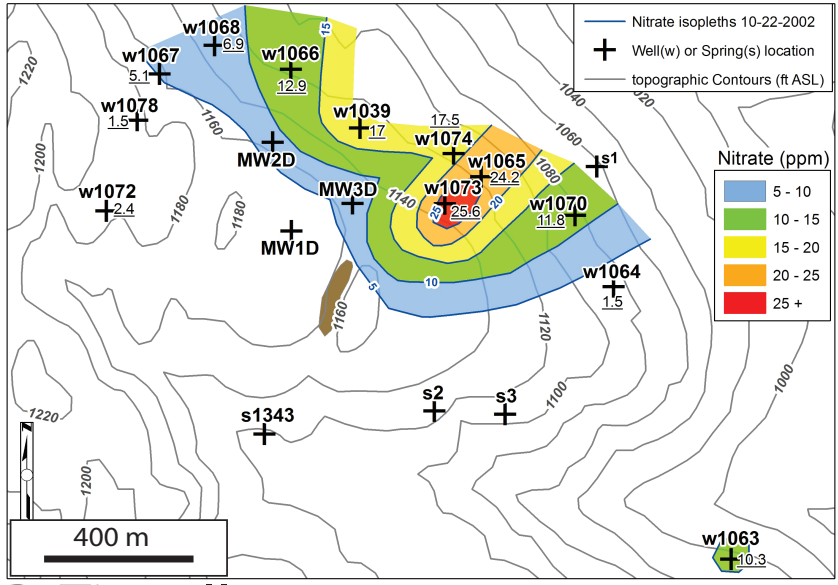

B. Time II- 10-22-2002

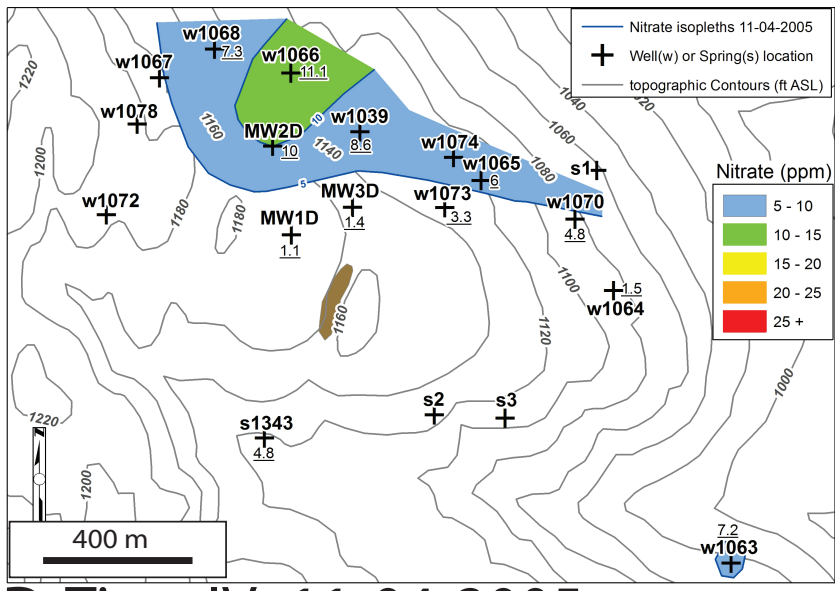

D. Time IV- 11-04-2005

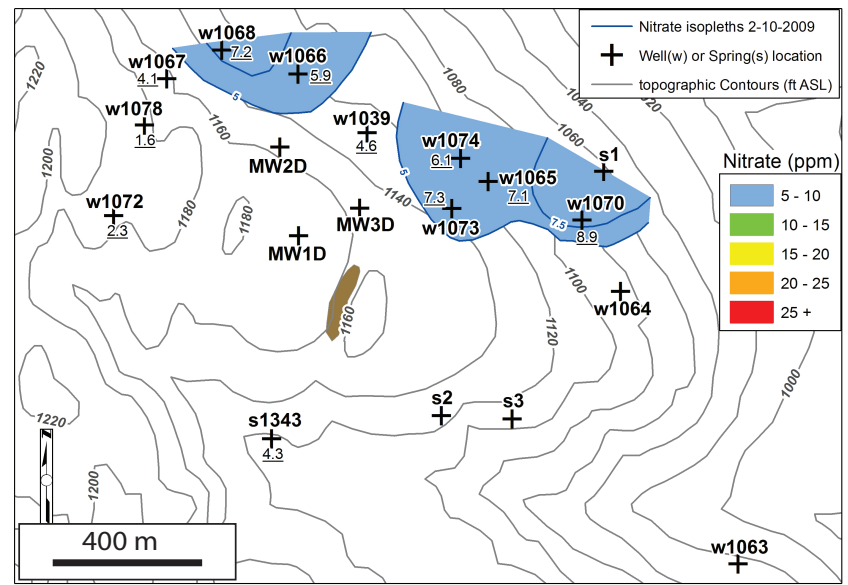

F. Time VI- 2-10-2009

Figure 6 
Figure 8

All Foliations
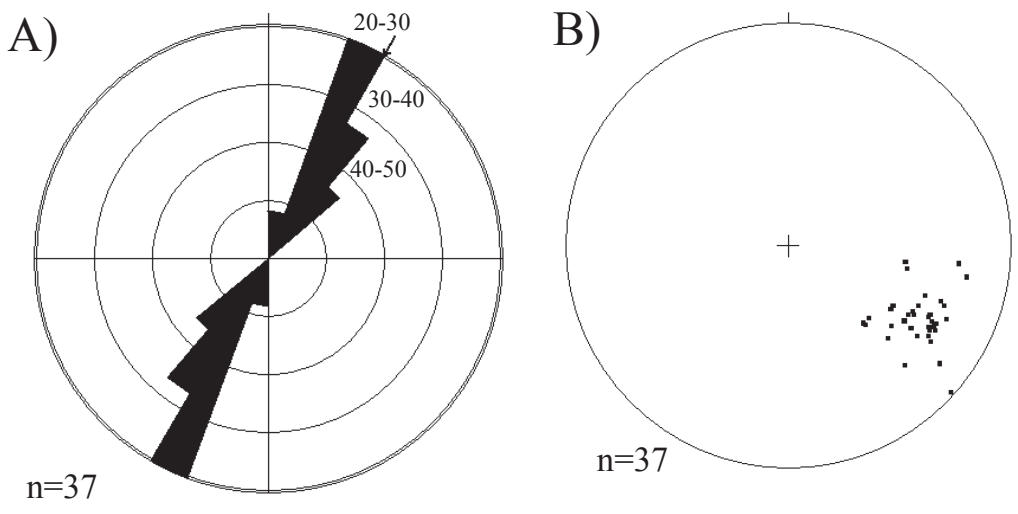

\section{All Fractures}

C)

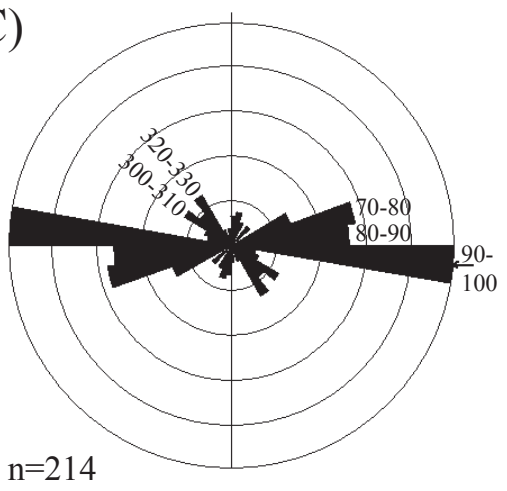

D)

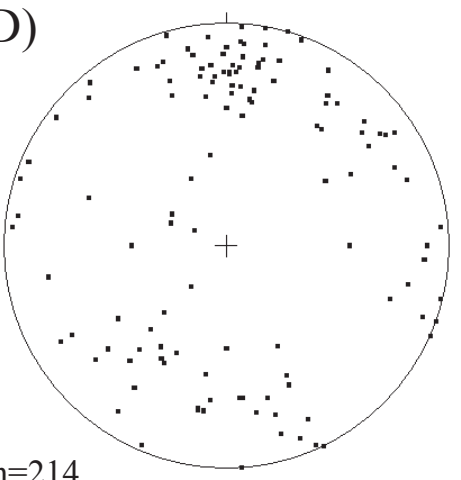

$n=214$

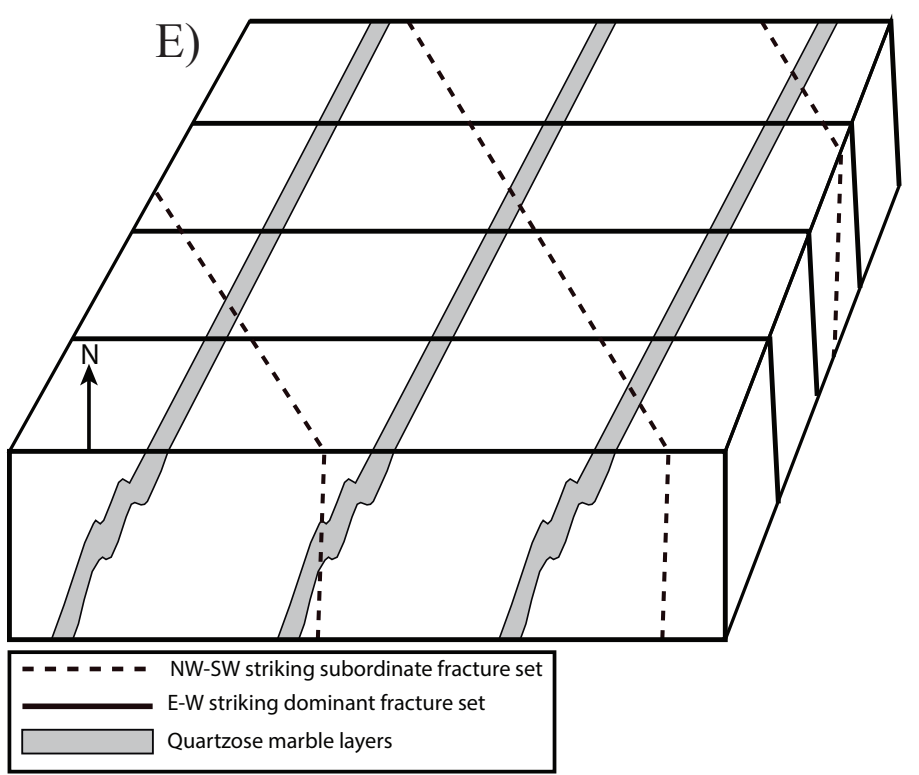




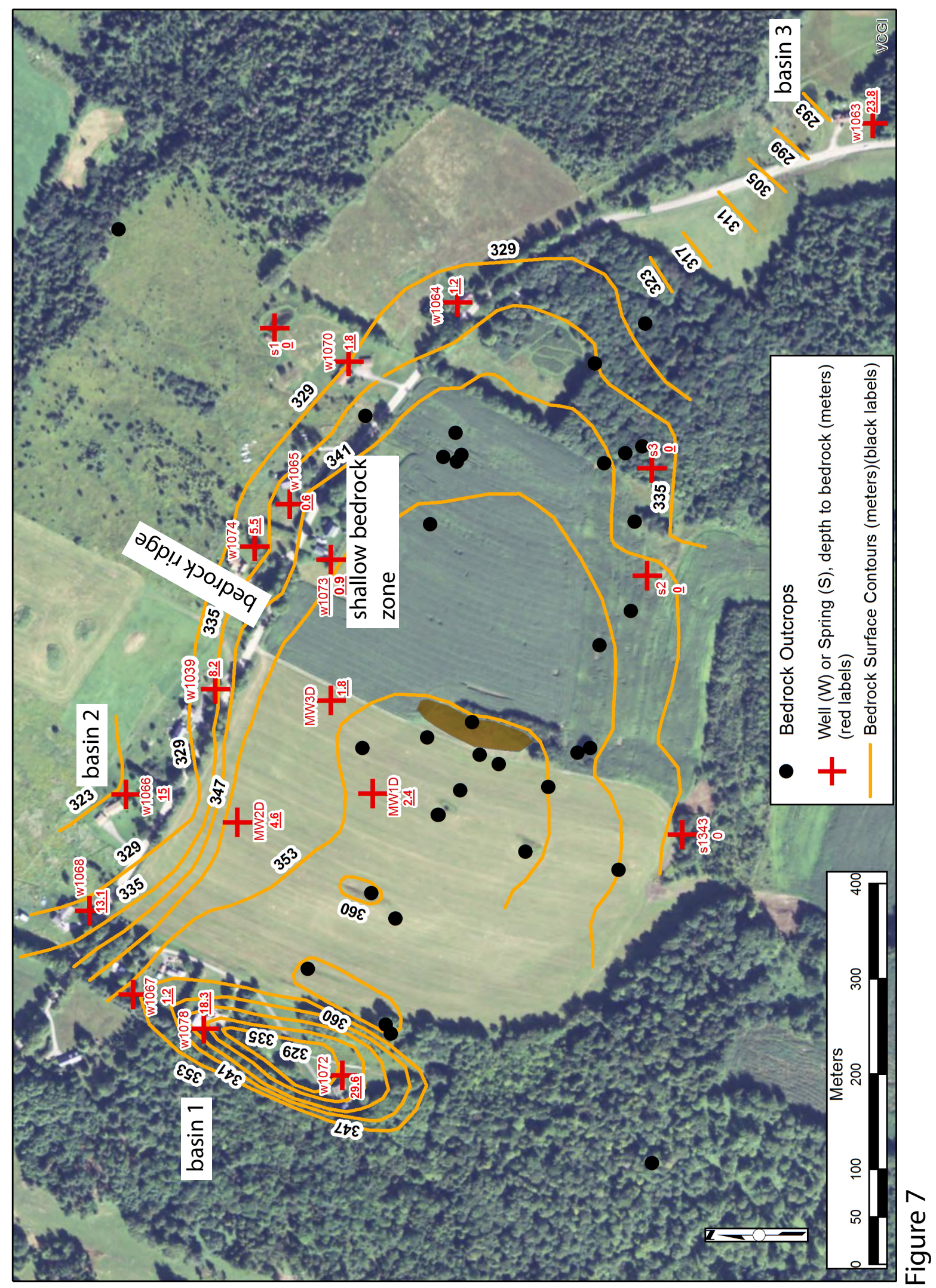



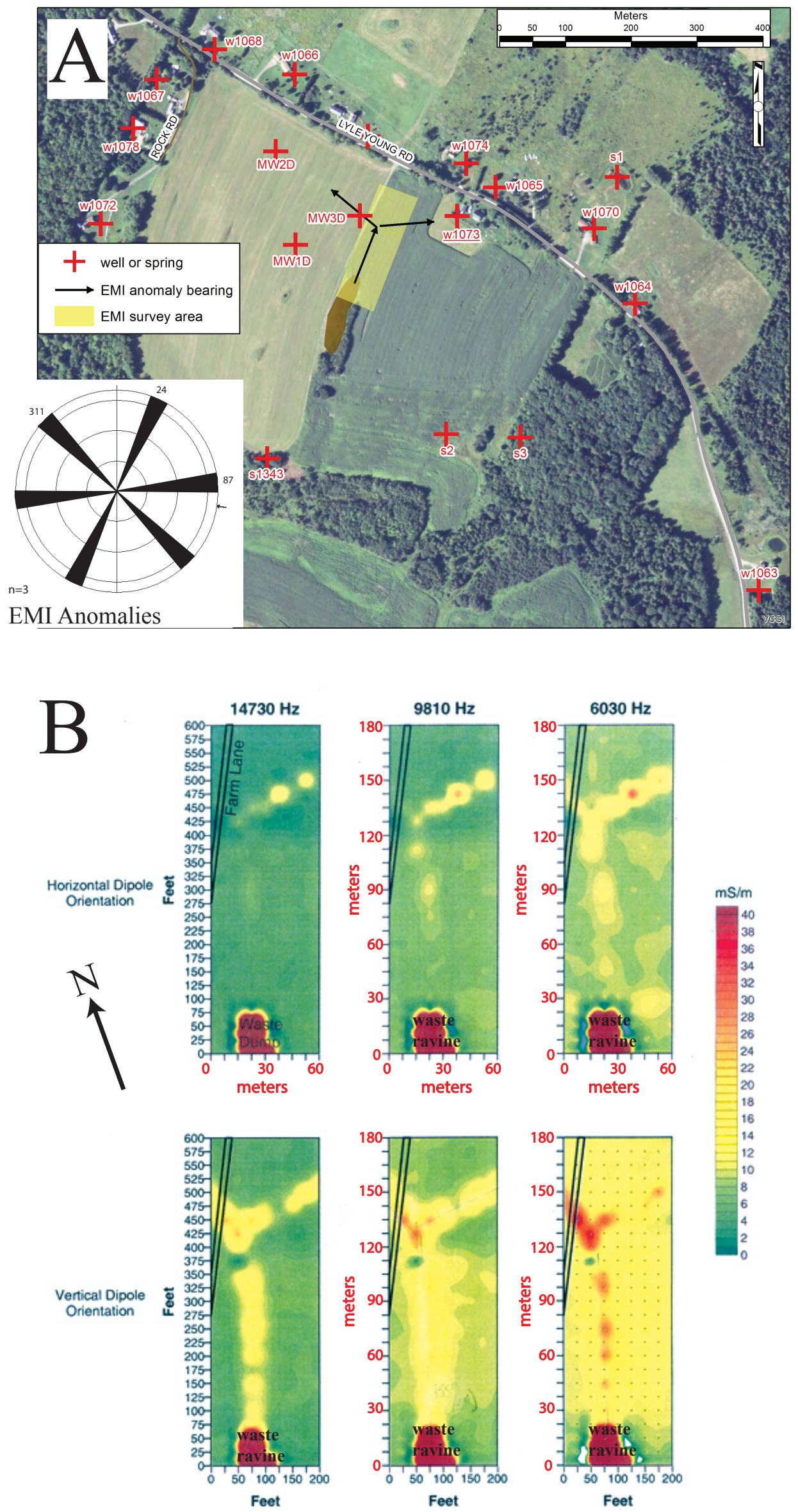


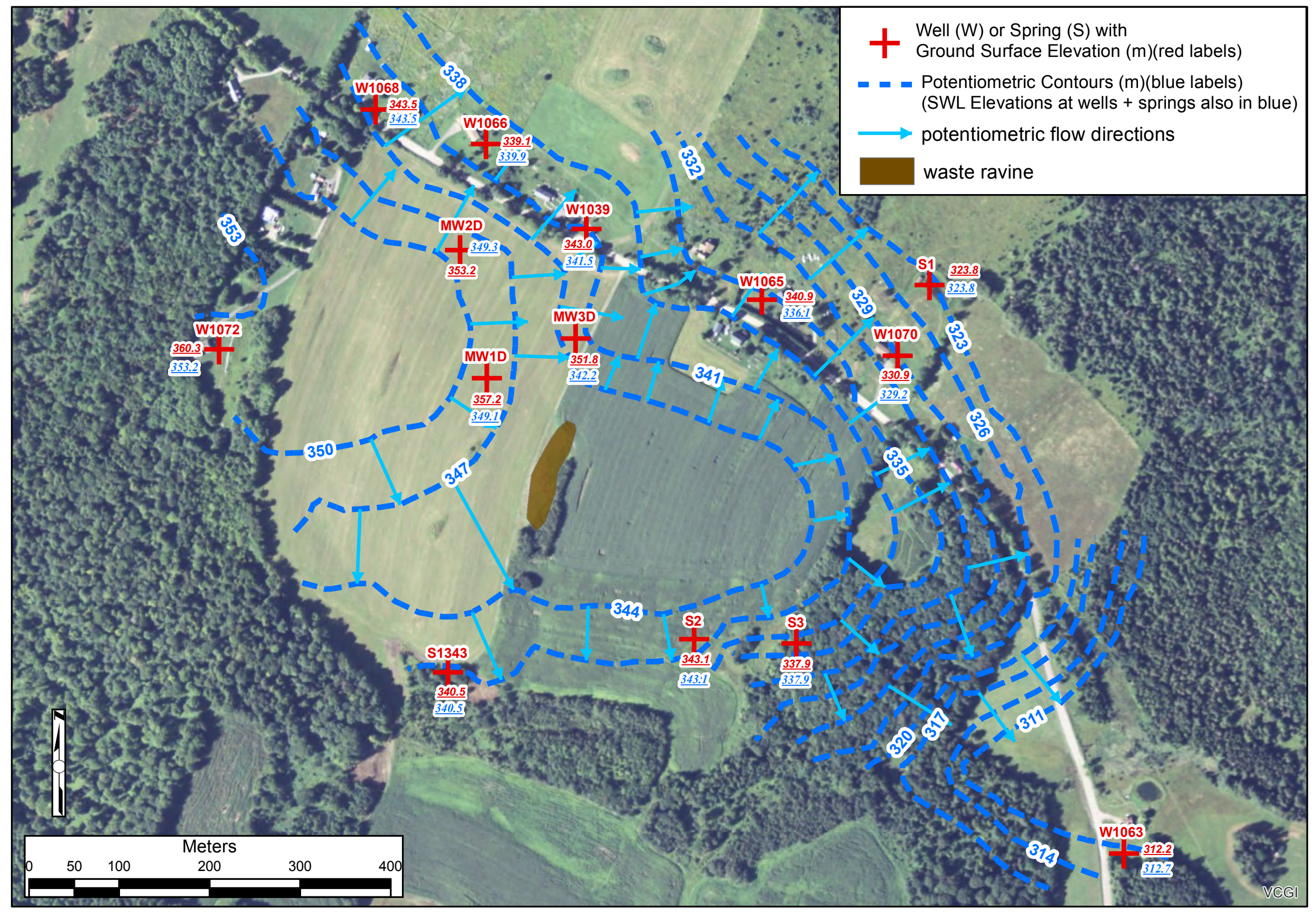




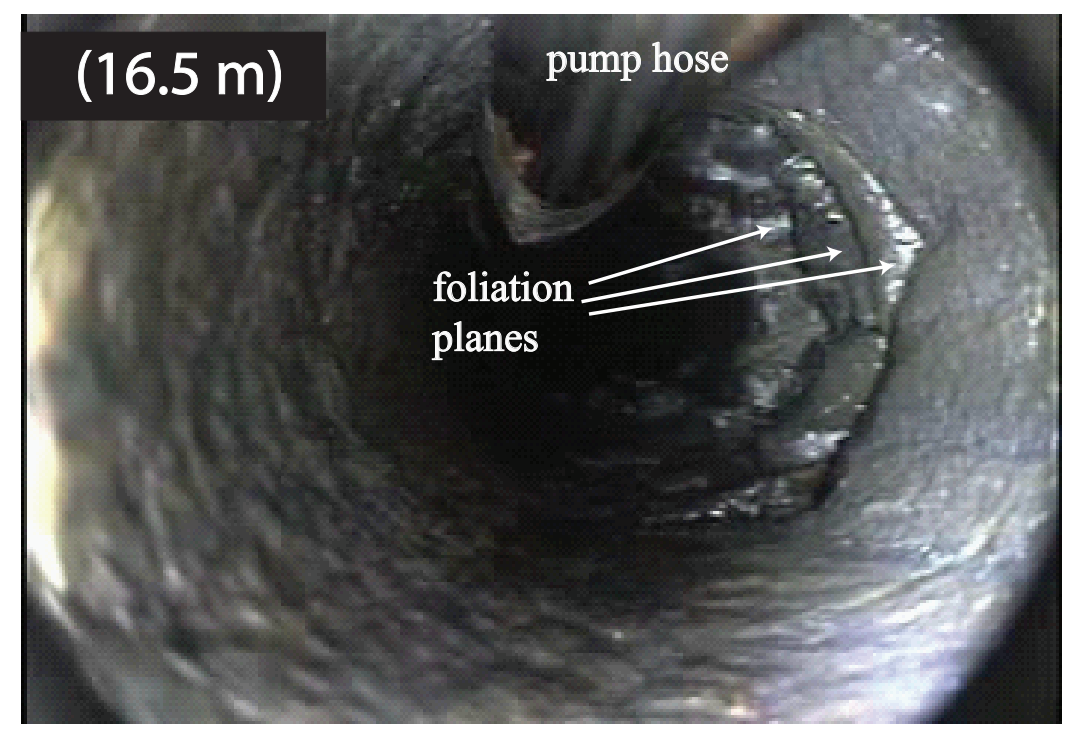

Figure 11A

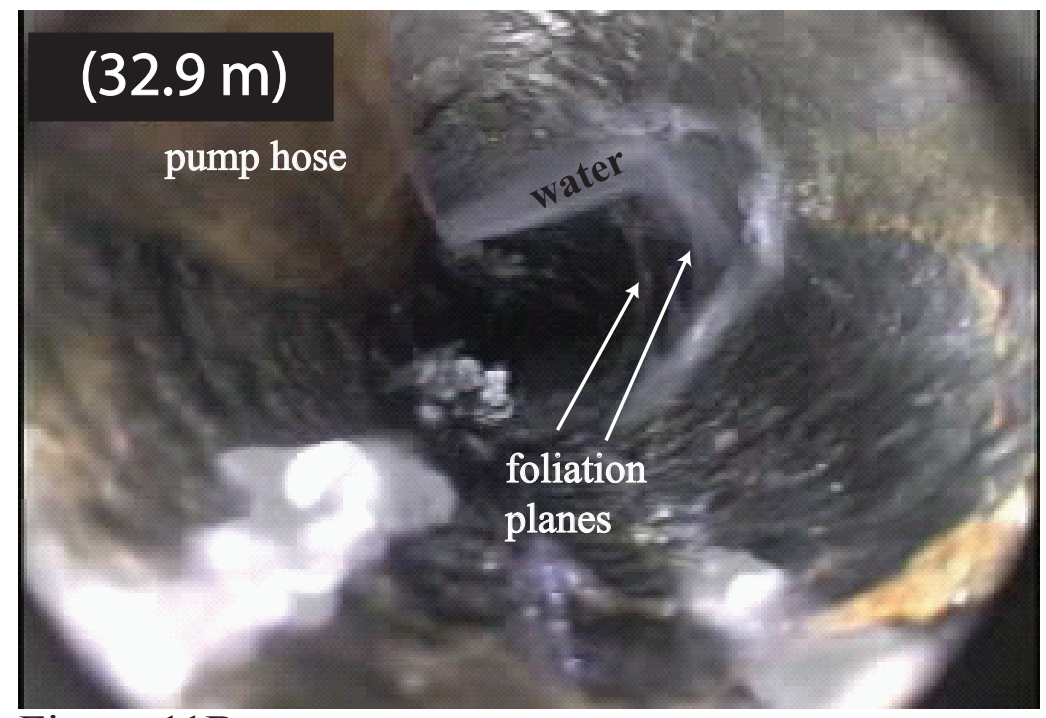

Figure 11B

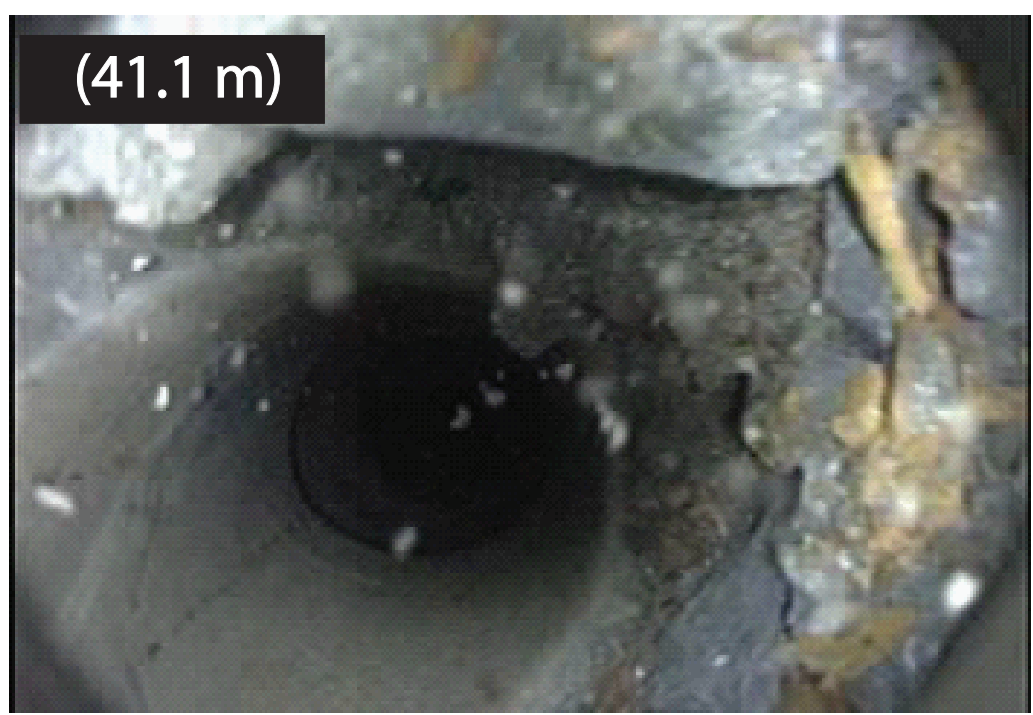

Figure 11C 

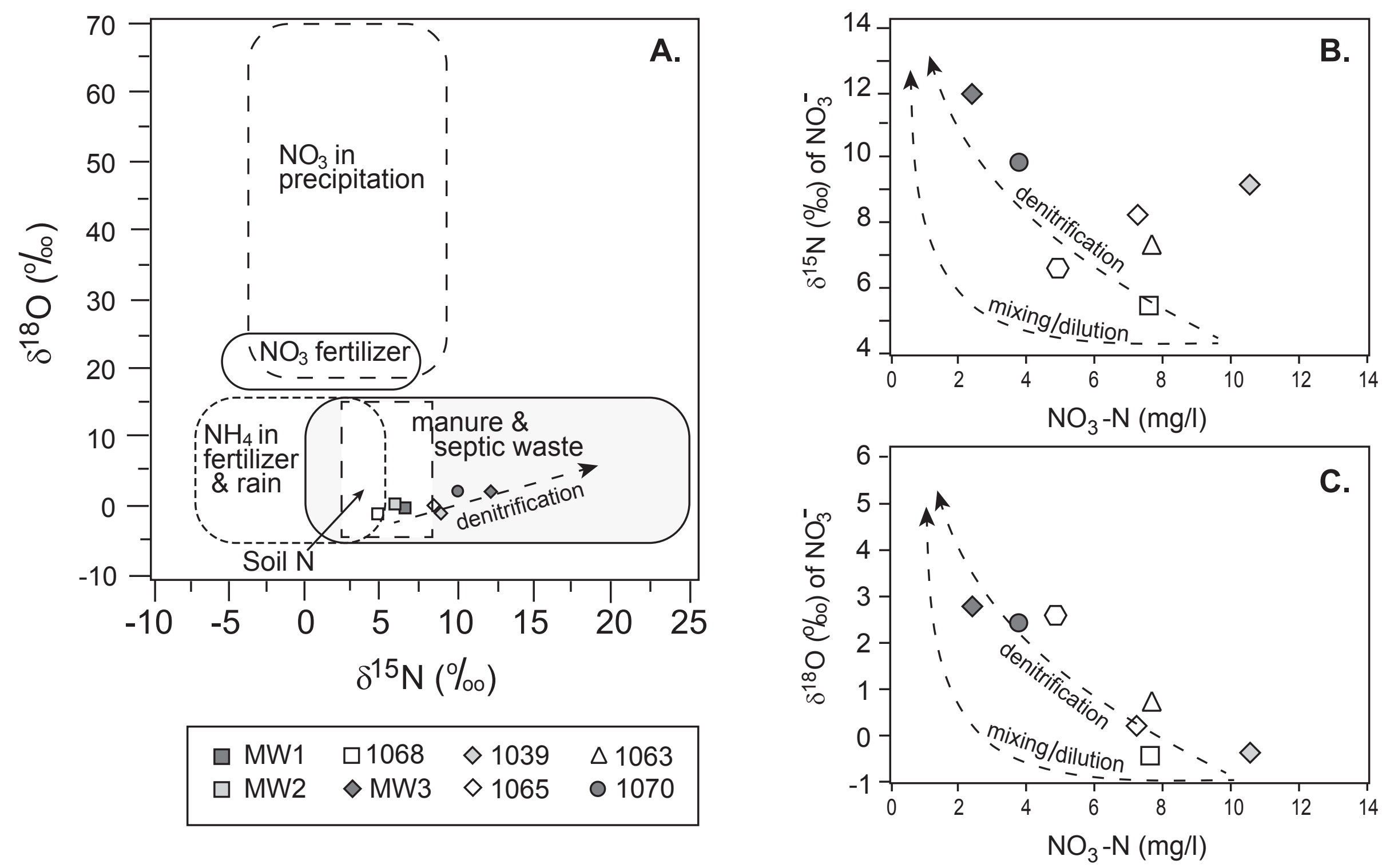
Figure 13
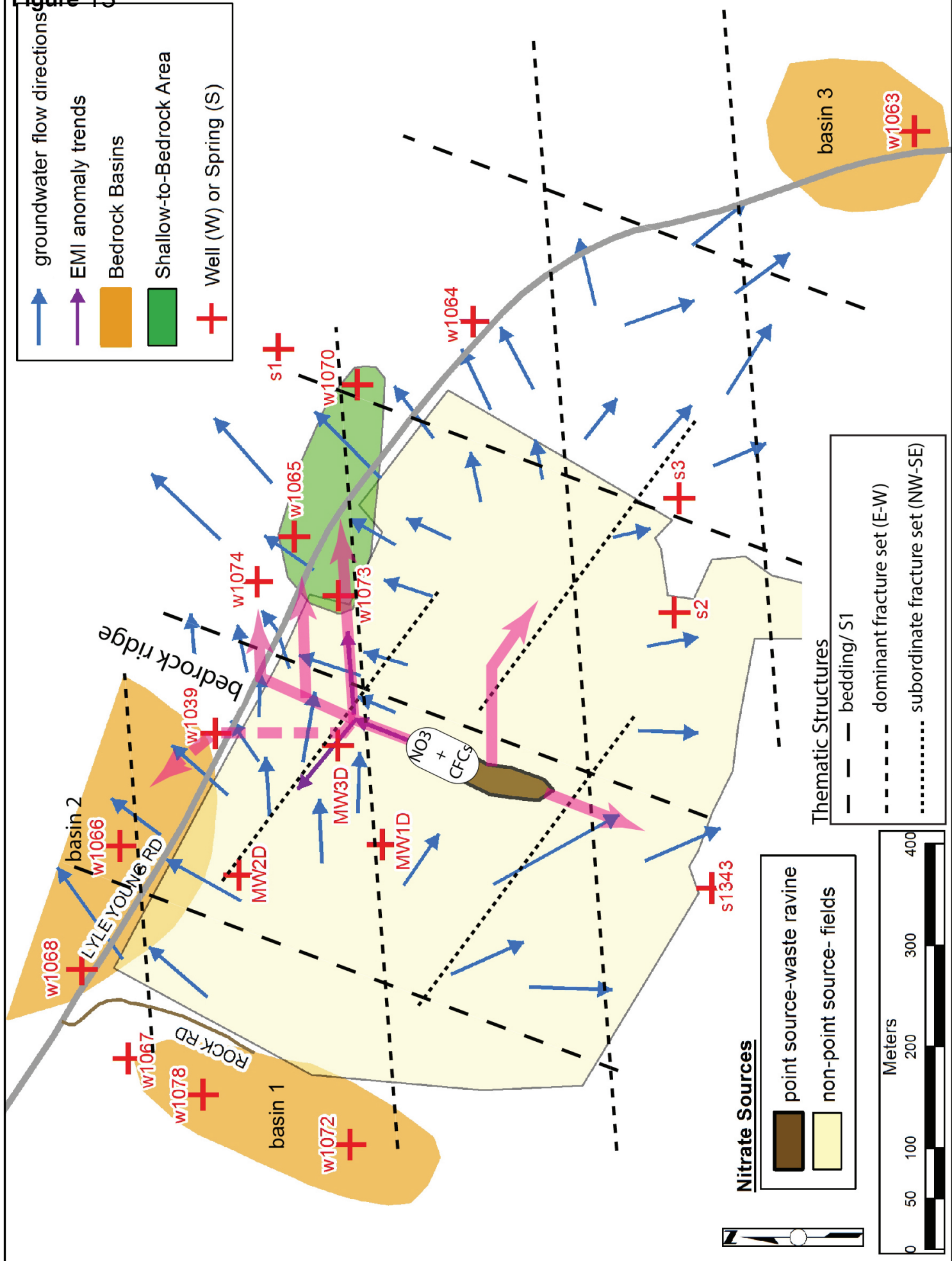


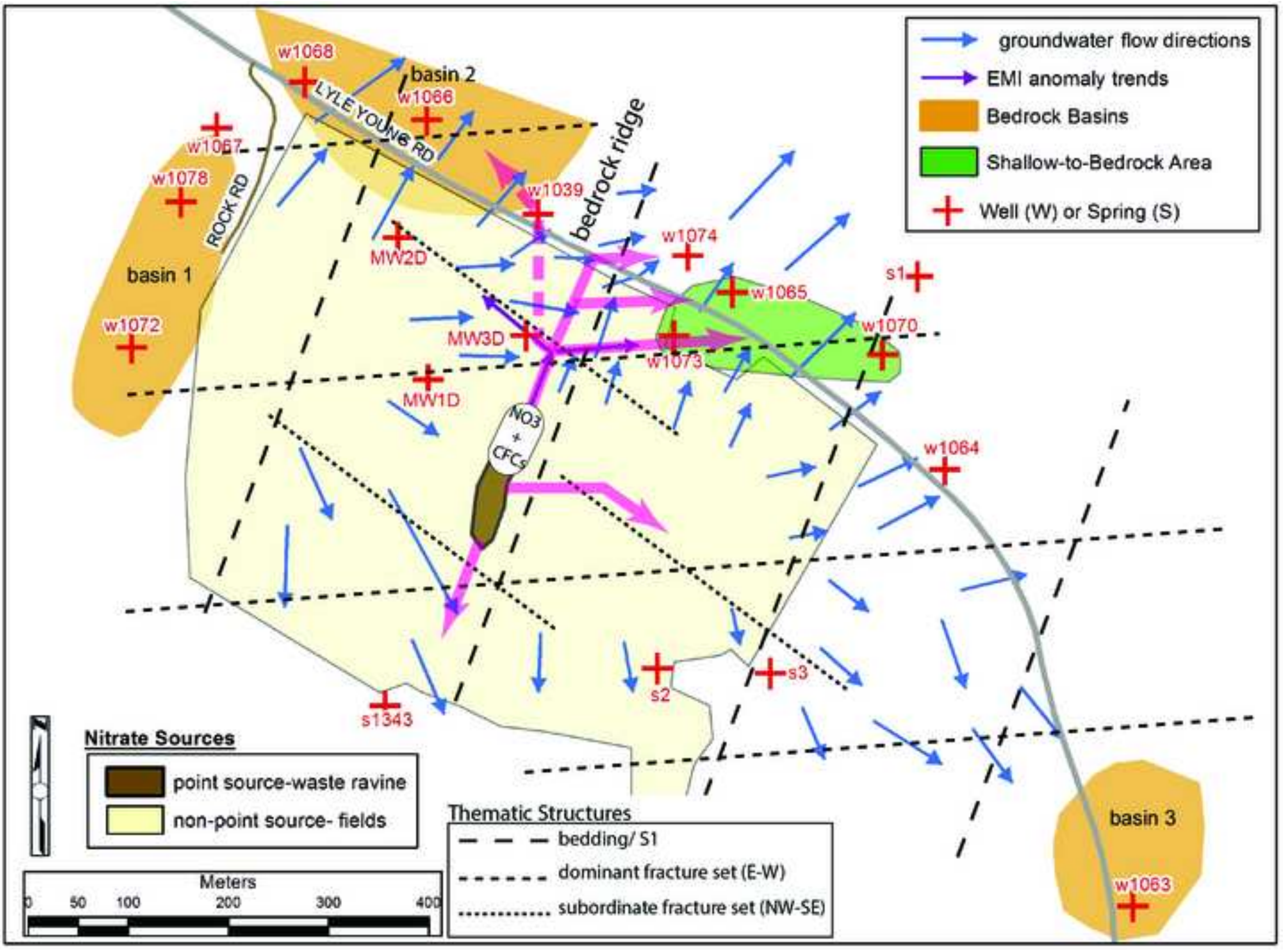

